\title{
The International Primary Care Respiratory Group (IPCRG) Research Needs Statement 2010
}

\author{
*Hilary Pinnocka, Mike Thomas ${ }^{b}$, loanna Tsiligiannic, Karin Lisspers ${ }^{d}$, Anders Østreme, \\ Björn Ställberg', Osman Yusuf ${ }^{\ddagger}$, Dermot Ryan ${ }^{\mathrm{h}}$, Johan Buffelsi, Jochen WL Cals', \\ Niels H Chavannes", Svein Høegh Henrichsen', Arnulf Langhammer ${ }^{\mathrm{m}}$, Elena Latyshevan, \\ Christos Lionis ${ }^{\circ}$, John Litt ${ }^{p}$, Thys van der Molen ${ }^{q}$, Nick Zwarr, Sian Williams ${ }^{s}$
}

a General Practitioner, Whitstable Medical Practice, Whitstable, Kent, UK; Senior Clinical Research Fellow, Allergy and Respiratory Research Group, Centre for Population Health Sciences: GP Section, University of Edinburgh, UK

b General Practitioner, Minchinhampton, Gloucestershire, UK; Asthma UK Senior Research Fellow, Centre for Academic Primary Care, University of Aberdeen, UK

General Practitioner, Agia Barbara Health Care Centre, Heraklion, Crete, Greece; University Medical Center of Groningen, The Netherlands

d General Practitioner, Gagnef Primary Health Care Centre, Gagnef, Sweden; Department of Public Health and Caring Sciences, Family Medicine and Clinical Epidemiology, Uppsala University, Uppsala, Sweden

e General Practitioner, Gransdalen Legesenter, Oslo, Norway

General Practitioner, Trosa Primary Health Care Centre; Department of Public Health and Caring Sciences, Family Medicine and Clinical Epidemiology, Uppsala University, Uppsala, Sweden

g Chief Primary Care/GP Trainer, and Consultant Allergy and Asthma Specialist, The Allergy \& Asthma Institute, Islamabad, Pakistan

h General Practitioner, Woodbrook Medical Centre, Loughborough, UK; PCRS-UK Clinical Research Fellow, Centre for Academic Primary Care, University of Aberdeen, UK

General Practitioner, Helix Network, Anderlecht, Belgium; Research Associate, Department of General Practice, K.U.Leuven, Leuven, Belgium GP trainee and Research Fellow, Department of General Practice, CAPHRI School for Public Health and Primary Care, Maastricht University, Maastricht, The Netherlands

k Associate Professor, Department of Public Health and Primary Care, Leiden University Medical Center, Leiden, The Netherlands General Practitioner, Langbølgen Legesenter, Oslo, Norway; Researcher, Department of General Practice and Community Medicine, University of Oslo, Norway

m General Practitioner, Hovdinggarden Medical Centre, Steinkjer, Norway; Associate Professor, HUNT Research Centre, Department of General Practice and Public Health, Norwegian University of Science and Technology, Trondheim, Norway

Allergologist, The Department of Allergology and Immunotherapy, Institute of Immunology, Moscow, Russia

- Head of Clinic of Social and Family Medicine, Professor of General Practice and Primary Care, School of Medicine, University of Crete, Heraklion, Crete, Greece

p Associate Professor, Discipline of General Practice, Flinders University, Adelaide, SA, Australia

a Professor, University Medical Center Groningen, Groningen, The Netherlands

General Practitioner, University Health Service, Sydney, Australia; Professor of General Practice, School of Public Health and Community Medicine, University of New South Wales, Sydney, Australia

Executive Officer, International Primary Care Respiratory Group,

Received 7th March 2010; accepted 11th March 2010

\footnotetext{
* Corresponding author: Dr Hilary Pinnock, Allergy and Respiratory Research Group, Centre for Population Health Sciences: GP Section, University of Edinburgh. Doorway 3, Medical School,Teviot Place, Edinburgh, EH8 9AG, Scotland, UK Tel: +44 (0)131650 8102 Fax: +44 (0)1316509119 E-mail: hilary.pinnock@ed.ac.uk
} 
H Pinnock et al.

\begin{abstract}
Aim: Respiratory diseases are a public health issue throughout the world, with high prevalence and morbidity. This Research Needs Statement from the International Primary Care Respiratory Group (IPCRG) aims to highlight unanswered questions on the management of respiratory diseases that are of importance to practising primary care clinicians.

Methods: An informal but inclusive consultation process was instigated in 2009. Draft statements in asthma, rhinitis, COPD, tobacco dependence, and respiratory infections were circulated widely to IPCRG members, other recognised experts, and representatives from a range of economic and healthcare backgrounds. An iterative process was used to generate, prioritise and refine research questions in each section.

Results: Two overarching themes emerged. Firstly, there is a real need for research to be undertaken within primary care, which recruits patients representative of primary care populations, evaluates interventions realistically delivered within primary care, and draws conclusions that will be meaningful to professionals working within primary care. Secondly, international and national guidelines exist, but there is little evidence on the best strategies for implementing recommendations. Disease-specific research questions focus on effective and cost-effective ways to prevent disease, confirm the diagnosis, assess control, manage treatment, and empower selfmanagement. Practical questions about how to deliver this comprehensive agenda in diverse primary care settings are highlighted.

Conclusions: We hope that this Research Needs Statement will be used by clinicians and patients campaigning for answers to relevant questions, by researchers seeking funding to provide answers to these questions, and by funding bodies to enable them to prioritise research agendas.

(C) 2010 Primary Care Respiratory Society UK. All rights reserved.

H Pinnock et al. Prim Care Resp J 2010; 19(Suppl 1): S1-S20.

doi:10.4104/pcrj.2010.00021
\end{abstract}

Keywords: asthma, rhinitis, COPD, smoking, tobacco dependence, respiratory, infections, IPCRG, research, strategies, primary care, guideline implementation, delivery of care

\section{Contents}

Funding, Acknowledgements AFC

Abstract

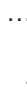

Contents

1. Introduction

1.1 The importance of primary care respiratory research

1.2 Methodology.....

1.3 The role of the IPCRG Research Needs Statement

1.4 Generic research questions

2. Asthma

2.1 Prevention

2.2 Diagnosis

2.3 Management, assessment of severity, asthma control and treatment

2.4 Management of acute asthma

2.5 Self-management

2.6 Organisation of asthma care

3. Allergic rhinitis

3.1 Epidemiology

3.2 Diagnosis

3.3 Rhinitis and asthma

3.4 Management

3.5 Self-management, and over-the-counter treatment

3.6 Organisation of care

4. COPD 58

4.1 Prevention .......................................... S8

4.2 Diagnosis of COPD in primary care .............. S9

4.3 Management .......................................... S9

4.4 Management of acute exacerbations ............ S10

4.5 Supported self-management ....................... \$10

4.6 Supportive and palliative care ..................... S11

4.7 Organisation of COPD care ........................ S11

5. Tobacco dependence ...................................... S11

5.1 Prevention .................................................. S11

5.2 National tobacco control policies ................... S11

5.3 Individual smoking cessation support ............ S12

5.4 Organisation of services ........................... S12

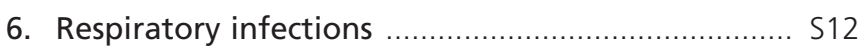

6.1 Prevention ................................................. S13

6.2 Diagnosis ............................................... \$13

6.3 Vulnerable subgroups and co-morbidities....... S13

6.4 Management ......................................... S13

7. Conclusion .................................................... S14

Conflicts of interest, Contributorship ....................... S14

References .................................................... S15 


\section{Introduction}

1.1. The importance of primary care respiratory research The core agenda of primary care research is to provide the evidence base for clinical and organisational issues relating to the treatment of common diseases, management of chronic diseases, and identification of risk groups. ${ }^{1}$ Respiratory disease exemplifies all these agendas. In many countries, respiratory symptoms are the commonest reason for presentation to primary care, encompassing both acute infections (pneumonia and the familiar if ill-defined 'chest infections') and long-term conditions such as asthma, rhinitis, and chronic obstructive pulmonary disease (COPD). Primary care clinicians worldwide have an important role in respiratory health promotion which includes vaccination programmes and smoking cessation.

Effective evidence-based medicine needs to be underpinned by methodologically robust research that answers questions that are relevant, recruits from representative populations, and acknowledges the diversity of contexts in which clinicians practise. From a primary care perspective, there are important gaps in the evidence base for common respiratory conditions which we highlight in this document. By excluding the elderly and those with co-morbidity, diseasefocussed research may be of direct relevance to only a minority of the patients seen in a typical primary care practice. ${ }^{2}$ Furthermore, global diversity (geographic, climatic, economic) and differences in healthcare organisation mean that evidence from one healthcare system may not be transferable to another.

\subsection{Methodology}

This Research Needs Statement from the International Primary Care Respiratory Group (IPCRG) aims to highlight unanswered questions of importance to practising primary care clinicians. The extensive list of contributors is testament to the broad range of countries represented.

The decision to update previous IPCRG Research Needs Statements ${ }^{3,4}$ was discussed by the IPCRG research committee in June 2009. As a result, an informal but inclusive consultation process was instigated. Summaries of early discussions were compiled by lead authors for asthma, allergic rhinitis, COPD, tobacco dependence, and respiratory infections. These were circulated to IPCRG members with a known interest in these areas and then more widely to recognised experts and representatives from a range of economic and healthcare backgrounds. An iterative process was used to generate, prioritise and refine research questions in each section. Finally, penultimate drafts were sent to the Senate members - who represent the 17 member and 21 associate member countries of the IPCRG - for further comment.

\subsection{The role of the IPCRG Research Needs Statement}

Thus this paper presents the research needs identified by an international group of respiratory-interested primary care professionals. We hope that the statement will be used by clinicians and patients campaigning for answers to relevant questions, by researchers seeking funding for work that will answer these questions, and by funding bodies to enable them to prioritise research agendas. It sits within the context of the draft World Health Organisation (WHO) research agenda for non-communicable diseases, which not only prioritises chronic respiratory diseases and tobacco control, but also specifically emphasises the core role of primary care in the management of long-term conditions. ${ }^{5}$

It also reflects, in the specific context of respiratory disease, the broad themes of generic primary care research priorities, including organisation of accessible, community-based, integrated care, clinical problem solving (encompassing diagnosis, treatment and management), and a comprehensive, holistic, patient-centred costeffective approach. ${ }^{1}$ A core message of all primary care research agendas (clearly echoed in this document) is the need for research undertaken within primary care, recruiting patients representative of primary care populations, evaluating interventions realistically delivered within primary care, and drawing conclusions that will be meaningful to professionals working within primary care.

\subsection{Generic research questions}

There are national and/or international guidelines available to inform management of all the conditions discussed in this document, but a common theme voiced by each of the section contributors was the concern that recommendations were poorly implemented and that research was needed to identify barriers and understand strategies to facilitate cost-effective implementation within different healthcare systems. ${ }^{6}$

\section{Research questions:}

- What sources of information do primary care clinicians use when assessing and treating patients with asthma, allergic rhinitis, COPD, smoking dependence, respiratory infections?

- What does the general practitioner (GP) really want from a guideline?

- What are the barriers to, and facilitators of, implementation of guidelines?

- What are the most effective ways of educating and updating primary care clinicians in the management of respiratory disease?

- Are guidelines applicable all over the world in the primary care setting?

\section{Asthma}

Its high prevalence makes asthma a worldwide public health issue. ${ }^{7}$ Globally, more than 300 million people of all ages suffer from asthma, of whom more than 250,000 die each year. ${ }^{8}$ This is not only of concern in (typically higher-income) countries where prevalence is greatest, ${ }^{7}$ but is also a challenge in low- and middle-income countries, where most asthma-related deaths occur. ${ }^{9}$

Improving the prevention and management of asthma is thus a high priority for primary healthcare in all countries. The Brussels Declaration advocates a ten point plan of action to improve evidence-based asthma management, emphasising the importance of including evidence from real life studies in treatment guidelines ${ }^{10,11}$ - an issue relevant to management of asthma throughout the world.

To promote high quality care, international and national asthma guidelines are updated regularly ${ }^{12-14}$ using evidence-based 
methodology, ${ }^{15,16}$ though the paucity of evidence from patients managed in primary care is acknowledged. ${ }^{14}$ By contrast, the IPCRG asthma guidelines aimed to highlight the special conditions in, and the evidence base from, primary care. ${ }^{17}$

This statement identifies research needs that should be given high priority in order to improve asthma care from the perspective of practising primary care clinicians.

\subsection{Prevention}

Various factors in early life have been associated with the recent increasing prevalence of asthma, although effective primary prevention strategies remain to be established. ${ }^{18}$ Although environments vary between and within different countries, exposure to smoke (including tobacco and indoor bio-mass fuel and coal burning) is a universal factor which impacts on the severity of asthma symptoms and the response to treatment, ${ }^{19-21}$ making reduction of exposure to smoke an important issue for primary care (see section 5). Occupational asthma is common, potentially preventable, but poorly recognised. ${ }^{22}$

\section{Research questions:}

- What are the important environmental risk factors (including indoor bio-mass fuel smoke, cigarette smoking and environmental pollution, aeroallergens, dietary and lifestyle factors) in different countries and what preventative measures can reduce effectively the prevalence and severity of asthma?

- Are primary care physicians aware of the allergens and respiratory irritants in their area? Are they aware of the preventive measures against such asthma triggers?

- What strategies will improve detection and prevention of occupational asthma in primary care?

\subsection{Diagnosis}

The diagnosis of asthma can be difficult, especially in patients with mild or intermittent disease seen in primary care, resulting in both under-diagnosis and over-diagnosis. ${ }^{23-26}$ Misdiagnosis might be due to inadequate professional training and/or interest, or limited healthcare resources. ${ }^{27,28}$

Under-diagnosis may be due to patients not consulting or not having access to clinical advice or diagnostic resources, or physicians' failure to consider the diagnosis when presented with non-specific symptoms (e.g. cough). Small children may be misdiagnosed with pneumonia or recurrent bronchitis. ${ }^{29}$ In countries where asthma is taboo, patients may seek another diagnosis rather than be labelled as "asthmatic". ${ }^{30}$ The characteristic variability of asthma means that there is a low sensitivity of objective measurements in patients during asymptomatic periods..$^{31,32}$

The common clinical scenario of 'wheezy infants' poses a particular challenge for primary care. The diagnosis is based on the history, signs and symptoms, ${ }^{33,34}$ and whilst the presence of atopy may strengthen the probability of asthma, diagnostic spirometry is not practical under the age of 5 years. ${ }^{35}$

The IPCRG guidelines suggest a range of symptom-based tools and investigations including peak flow monitoring, spirometry, reversibility testing and challenge tests, ${ }^{36}$ and a recent international statement summarises the technical details. ${ }^{37}$ Information on the sensitivity, specificity, positive and negative predictive value of such tools in primary care settings is needed to inform best practice. Such data will need to be context-appropriate, not only reflecting diverse primary care populations but also recognising the different availability of diagnostic tools in different countries.

\section{Research questions:}

- How can asthma be diagnosed earlier in primary care?

- What is the role of symptom-based tools for diagnosing asthma in primary care?

- What are the reliability, validity and feasibility of different diagnostic tools such as spirometry, peak-flow measurement, challenge tests, exhaled nitric oxide and allergy testing in the diagnosis of asthma in primary care?

- What are the cut-off values for abnormal spirometry (lower limit of normal), reversibility tests and diurnal variation of peak-flow measurement across a broad range of age groups and ethnicity?

- How can rural and remote areas or developing countries diagnose and manage asthma with limited or no availability of diagnostic tests?

- What is the reliability of a medication trial for diagnosing asthma in different ages, how should such tests be performed, using which treatments and for how long?

Children:

- To what extent are small children with recurrent wheeze misdiagnosed in primary care and with what consequences for morbidity?

- What practical algorithms could distinguish between recurrent wheeze/asthma and other acute respiratory diseases including pneumonia for young children presenting to primary care?

- Is it possible to predict persisting asthma in children with wheeze in primary care?

\subsection{Management, assessment of severity, asthma control and treatment}

Studies have consistently demonstrated widespread poor asthma control, implying that the management of asthma could be improved. ${ }^{38-41}$ Guidelines highlight the importance of developing a partnership between the doctor and the patient $\mathrm{t}^{12-14,36}$ so that regular professional review and monitoring of people with asthma is combined with appropriate treatment recommendations and selfmanagement education to enable patients to achieve treatment goals. $^{42}$

The dual concepts of asthma severity and asthma control have been widely discussed. ${ }^{43-45}$ Recent guidelines have changed their emphasis from classification of severity to the goal of achieving asthma control, ${ }^{12}$ prioritising the objective assessment of control. 
Structured morbidity scores can be used to quantify patients' reports of their asthma symptoms over a period of time. ${ }^{46-54}$ Although such questionnaires have been validated for research purposes, few have been validated for assessing individual asthma control in a clinical context. Suboptimal control is associated with concomitant rhinitis, other co-morbidities, smoking, poor inhaler technique and poor concordance with treatment, ${ }^{40}$ but there is further need for studies enrolling patient populations seen in primary care to inform practice. $^{40}$

Management should reflect the heterogeneity of asthma. Children and adults may have persistent or episodic asthma, triggered by viral infections, allergens or exercise. ${ }^{12,33}$ Asthma in pregnancy requires proactive management to optimise outcomes for mother and baby. ${ }^{14}$ Asthma and rhinitis often co-exist in the same patient. ${ }^{55}$ Other important co-morbidities which may invite alternative approaches - often overlooked by disease-specific guidelines but of significance to primary care clinicians - include COPD, cardiovascular disease, gastro-oesophageal reflux, obesity, psychological morbidities and dysfunctional breathing.

Pharmacotherapy for asthma includes regular 'controllers' (or 'preventers') which improve control and reduce the risk of exacerbations, and as-required 'reliever' medications which reverse airflow limitation and reduce symptoms. Guidelines, which are based on an extensive pharmacological evidence base, emphasise early regular treatment with a 'controller', though allergen avoidance may also be a consideration. Randomised trials suggest that inhaled corticosteroids (ICS) are the most efficacious 'controller', with no clinically relevant side effects at low to moderate doses. ${ }^{12-14,36}$ Efficacy trials of alternative 'controllers' (e.g. anti-leukotrienes, LTRAs) in moderate asthma conclude that ICS produce better outcomes, though whether this is true for all patients with mild or intermittent asthma is debated. ${ }^{56-57}$

Such trials do not address the practical issues that impact on effectiveness in real-life primary care practice such as inadequate inhalation technique, ${ }^{58}$ perceived side effects of steroids, ${ }^{59}$ patient preference for regular treatment, and the impact of adherence..$^{60}$

\section{Research questions:}

Monitoring and assessing asthma control:

- What simple tools enable assessment of asthma control, and is their use acceptable and feasible in primary care?

- Is an assessment of severity needed in addition to an assessment of asthma control in primary care?

- What is the role of lung function testing in regular monitoring of asthma patients in primary care?

- What is the role of nitric oxide, mannitol challenge testing (or other innovative techniques) in the monitoring of asthma in primary care?

- What is the validity and usefulness of questionnaires for assessing quality of life (or other outcomes) when used for individual patients in routine primary care clinical practice.

- Why do patients accept suboptimal asthma control, and how can we address the reasons?

- How do co-morbidities impact on asthma control and management?

Adherence:

- What is the impact of patients' comprehension of the disease, use of different treatment strategies, treatment cost (in high income and low income countries and between social groups) and concern about side effects of inhaled steroids on adherence to prescribed treatment?

- How may these issues of adherence be addressed (especially in sub-groups such as the adolescent patient with asthma)?

Inhalation technique and usage:

- How can good and poor inhaler technique be identified and what is the best strategy for ensuring good inhaler technique?

- What is the most cost effective approach to inhaler devices?

- What strategies are needed to counteract the taboos associated with inhaler usage in some countries?

Non-pharmacological management and management of co-morbidities:

- What is the impact of non-pharmacological strategies e.g. breathing modification, allergen avoidance techniques - in the management of asthma symptoms?

- Does the detection and treatment of co-morbidities (anxiety and depression, obesity) improve outcomes for people with asthma?

Treatment:

- How do ICS and LTRAs compare with regards to effectiveness and side-effects in patients with mild and moderate asthma in real-life primary care practice?

- What is the most effective add-on therapy option to ICS in different sub-groups of asthma?

- How and when should regular medication be stepped down or stopped?

- Can specific asthma phenotypes be identified in primary care and what are the implications for treatment and management in primary care?

Children:

- What is the impact of different treatments for wheezing in young children in primary care?

\subsection{Management of acute asthma}

Guidelines offer advice on the assessment, therapeutic management and organisation of care for acute asthma, though audits consistently show that compliance with recommendations is poor. ${ }^{61-64}$ Although the management of acute asthma in different countries is dependent on resources and the organisation of care, a key skill for primary care in any healthcare setting is objective assessment of severity. ${ }^{12-14,36}$ Most exacerbations seen in primary care are moderate, ${ }^{61,63}$ but prompt recognition of life-threatening attacks, appropriate management, and close supervision of severe asthma may prevent deaths. 


\section{Research questions:}

- How can services be configured to ensure that front-line clinical staff assess and manage acute asthma attacks according to evidence-based practice?

- What is a practical approach to the assessment of the severity of acute asthma in primary care in settings with limited diagnostic resources?

- What is the preferred management (including appropriate inhalation device) of moderate exacerbations in primary care, including in clinical situations where treatment options are limited?

- What are the indications for referral to an emergency unit?

- How should acute severe asthma be managed in settings where emergency departments and hospitals are not accessible?

- What is the importance of co-morbidity (especially psychological morbidity) and socio-economic factors in identifying those at risk of very severe attacks?

\subsection{Self-management}

Asthma is a variable condition and patients need advice to help them understand their illness and their own particular triggers, recognise changes in their control, and to act appropriately. There is an extensive evidence base demonstrating that the provision of selfmanagement education supported by written action plans as part of regular asthma reviews improves outcomes. ${ }^{65-67}$ Although this approach - known as 'guided self-management' - is endorsed by guidelines, ${ }^{12-14,36}$ there is evidence of widespread underuse in clinical care. ${ }^{68,69}$ Despite evidence from primary care studies, ${ }^{70-73}$ there is a perception that such plans may not be appropriate for people with mild disease. ${ }^{69}$ There is a paucity of evidence to inform implementation of self-management education, ${ }^{14}$ though some evidence that a link with routine reviews is important. ${ }^{73-77}$ Specifically, there is a need for more knowledge about the contents of the plans in relation to the asthma severity and individual requirements.

\section{Research questions:}

- How can guided self-management be implemented in real life primary care practice?

- Why are professionals reluctant to provide asthma action plans to their patients, and how may this be overcome?

- What are effective approaches to developing a partnership with the patient?

- What are the important components of selfmanagement education, and how can they best be conveyed to the patient/family in routine practice?

- How should action plans accommodate the different asthma treatment schedules?

- How, and to what degree, are asthma action plans implemented in various communities, especially in low and middle income countries, and how do they impact on asthma morbidity and mortality?
- How might asthma action plans be tailored for different ethnic groups, taking into account their cultural beliefs and practices?

\subsection{Organisation of asthma care}

The organisation of asthma care differs between countries depending on economic factors, health care systems and traditions. In some countries, nurses with a special interest in asthma work independently or in co-operation with GPs managing asthma patients. ${ }^{78}$ Modern information technology offers new opportunities for remote consulting ${ }^{79-81}$ and tele-monitoring of asthma, ${ }^{82}$ which may facilitate convenient care or overcome accessibility problems in remote areas. ${ }^{83}$

\section{Research questions:}

- Are any models of health care better than others in terms of clinical and cost-effectiveness for the management of asthma?

- What is the influence of cultural and ethnic beliefs towards asthma and how do these beliefs affect outcome in management of asthma in these communities?

- What is the role of mobile technology, web-resources and remote consultations in the management of patients in primary care?

\section{Allergic rhinitis}

Allergic rhinitis affects over 600 million people of all ages, and globally is increasing in prevalence. ${ }^{55}$ It causes a greater impairment of quality of life than asthma, ${ }^{84}$ a disease which it may precede or accompany in up to $80 \%$ of cases. ${ }^{85}$ Together, allergic rhinitis and asthma represent an important socioeconomic burden..$^{86,87}$

Recent reports have highlighted the unmet needs of people with allergic rhinitis, ${ }^{88}$ and argued for increasing adherence to guideline recommendations. However, guidelines for the management of allergic rhinitis need to reflect the primary care context if they are to be adopted in primary care. ${ }^{6}$ We propose a series of research topics selected to meet current and future needs in primary care.

\subsection{Epidemiology}

Widespread under-diagnosis means that there is still insufficient data about the epidemiology of allergic rhinitis. ${ }^{89-92}$

\section{Research questions:}

- What is the hidden burden of undiagnosed allergic rhinitis in different countries?

\subsection{Diagnosis}

Globally, allergic rhinitis is under-diagnosed, mis-diagnosed, and therefore, under- and mis-treated and managed..$^{93}$

Under-diagnosis may occur as patients' assumption that they are suffering from the common cold is reinforced by a friend, or the pharmacist from whom they purchase over-the-counter (OTC) medication. ${ }^{93}$ Reliance on self-diagnosis is common, with a delay of many years before seeking professional advice. ${ }^{94}$

When the symptoms become severe, or home remedies fail, ${ }^{95}$ 
and the patient consults their primary care clinician, ${ }^{96-98}$ failure to take an adequate medical history, perform a clinical examination, and initiate appropriate diagnostic tests means the diagnosis may be still be overlooked. ${ }^{99}$ Heavy demand for GPs' services may lead to trivialisation of rhinitis. ${ }^{99}$ Although a pattern of symptoms that make a diagnosis likely has been proposed, ${ }^{55}$ there is no short, validated, symptom-based instrument to assist diagnosis in primary care.

In regions where local 'pollen calendars' are available, a good history is usually sufficient to identify the allergen with a reasonable degree of reliability, though intermittent symptoms from variable levels of house dust mite allergen can cause confusion. Unfortunately, such seasonal information is not universally available.

Skin prick testing is the "gold standard" of allergy testing, and is recommended to support the clinical assessment of those with persistent or moderately severe disease, uncontrolled with conventional medication, ${ }^{55}$ reserving the expensive allergen-specific IgE test for situations when (or where) skin testing is not possible.

\section{Research questions:}

- What are the common local indoor and outdoor allergens, and what is the local 'pollen / allergen calendar' for allergenic pollens, fungi (moulds), dusts and other aero-allergens?

- What tools (e.g. validated, symptom-based questionnaires for rhinitis or screening for atopy ${ }^{100}$ ) could help the primary care clinician differentiate between allergic and non allergic rhinitis, rhino-sinusitis, the common cold and other clinically similar conditions?

- What are the essential components of physical examination in primary care?

- What is the value of, and how feasible are, skin-prick tests and other tests in the diagnosis and management of allergic rhinitis in primary care in diverse healthcare settings? Does performance of these tests affect clinical outcomes?

- What is the availability of OTC remedies in different countries, and the diagnostic and management skills of those who sell or advise on their administration?

\subsection{Rhinitis and asthma}

Rhinitis and asthma co-exist in a large proportion of patients, with rhinitis often preceding asthma. ${ }^{85,101}$ In atopic children, the presence of allergic rhinitis is a risk factor for asthma, with a time interval of about a year before the development of asthma symptoms, ${ }^{102}$ offering a potential window of opportunity when early detection and appropriate management of rhinitis may prevent the progression to asthma.

Co-morbid rhinitis is associated with increased asthma symptoms, increased exacerbations and hospital admissions, ${ }^{103-105}$ with some evidence that concomitant treatment can improve control. ${ }^{106,107}$

\section{Research questions:}

- Are clinicians aware of the asthma-rhinitis link, and to what extent do they seek information about allergic rhinitis when seeing asthmatic patients?

- Does early and aggressive treatment of atopic children with allergic rhinitis (e.g. with topical nasal steroids, and/or immunotherapy) prevent the progression to asthma?

- What (combinations of) management strategies for treating rhinitis improve asthma control, and/or improve quality of life?

- Does nitric oxide measurement have a role in the diagnosis and management of patients with allergic rhinitis in primary care?

\subsection{Management}

The main goal of treatment is to achieve control of the disease, ${ }^{55}$ but tools capable of assessing the control of both upper and lower airways diseases are lacking. ${ }^{108}$ The ARIA guideline proposes a classification based on both severity of symptoms and whether symptoms are intermittent and persistent. ${ }^{55}$

Guidelines provide evidence-based recommendations to inform the management of allergic rhinitis under the headings 'allergen avoidance', 'pharmacological treatment', and 'specific immunotherapy'. 5 , 109-111 Allergen avoidance can be effective for reducing the symptoms of allergic rhinitis, ${ }^{112-115}$ though single interventions may be insufficient to control symptoms. ${ }^{116}$ Non pharmacological measures with some efficacy include saline douches, ${ }^{55,117-120}$ rhinophototherapy, ${ }^{121}$ nasal filters, ${ }^{122}$ pollen-blocker creams, ${ }^{123}$ or cellulose powder. ${ }^{124}$ Facemasks and eyeglasses may offer some protection, ${ }^{125}$ and probiotics may influence symptoms of allergic diseases. ${ }^{126,127}$

Guidelines describe a stepped approach to pharmacological treatment with (second generation) antihistamines and topical nasal corticosteroids as first line treatment, which may be combined with leukotriene-receptor antagonists, cromolyn, short-term topical or systemic decongestants, intranasal antihistamines, and intranasal anticholinergics for additional symptom relief. ${ }^{55,128,129}$ Practical questions about how to identify patients who would most benefit from treatment, ${ }^{96}$ and the management of people with comorbidity, remain to be answered.

Despite advice that they have a limited role in the management of allergic rhinitis, systemic steroids are frequently used in the management of allergic rhinitis in many parts of the world. Depot corticosteroids are popular for practical reasons, and a recent systematic review suggested a potentially useful role in patients suffering from intermittent but severe rhinitis, though the lack of safety data raises concerns about adverse effects. ${ }^{130,131}$

Although a consensus is emerging that immunotherapy should be considered for patients with moderate to severe allergic rhinitis who have not responded to optimal medical therapy and allergen avoidance, ${ }^{132}$ a greater understanding is required of its effectiveness and safety in different primary health care settings.

\section{Research questions:}

Monitoring and assessing control:

- What questions for use in primary care practice will determine rhinitis control, and identify those at risk of 
worsening symptoms and/or onset of co-morbid asthma?

- Is the ARIA classification ${ }^{55}$ useful in guiding prescribing in primary care?

Non-pharmacological management and management of co-morbidities:

- What role does allergen identification and avoidance have in the management of rhinitis? Does this vary according to the geographic, climatic and demographic context?

- To what extent do patients with allergic rhinitis use alternative medicines? (e.g. homeopathy, herbal treatment etc)

- What is the acceptability to patients and impact on the morbidity of rhinitis / asthma of physical measures (e.g. nasal douches, nasal lubricants, closing windows at night) Inhalation technique and usage:

- What is the best technique for using nasal sprays? What do doctors, pharmacists, and patients know of correct nasal inhalation technique?

Treatment:

- What is the cost-effectiveness of different treatment regimens in healthcare systems with diverse socioeconomic and financial status?

- How should patients with other respiratory conditions (e.g. asthma, COPD, sleep apnoea), or other comorbidities (e.g. hypertension, diabetes mellitus, heart disease, liver disease) or physiological states (e.g. pregnancy, extremes of age) be managed?

- What evidence is there for the safety and efficacy of systemic steroids in the treatment of rhinitis? Are there differences between existing systemic therapies (e.g. oral, intra-muscular?)

- For which patients is immunotherapy (sublingual or injection) appropriate, safe and cost effective? Should such treatment always involve a referral for a specialist care?

3.5. Self-management, and over-the-counter treatment Patients often rely for many years on 'over-the-counter' medication with limited effectiveness and may experience adverse effects (e.g. drowsiness with first generation antihistamines, ${ }^{133-135}$ rhinitis medicamentosa with prolonged use of topical decongestants) to which the GP should be alert. Incorrect use of medication (e.g. topical nasal steroid sprays), inadequate dosages, and poor compliance, all contribute to treatment failure. Pharmacists and primary care clinicians have an important role in providing information and treatment. ${ }^{136-138}$

\section{Research questions:}

- What non pharmacological remedies do patients use to treat their rhinitis?

- What strategies can be used to reduce the risk of sideeffects from self-treatment?

- How can compliance with treatments be improved?
- Are patients' information needs being met, with accurate, easily accessible, and culturally sensitive resources? ${ }^{137,138}$

\subsection{Organisation of care}

Despite specific recommendations from the World Allergy Organisation about inclusion of an allergy module within the undergraduate medical curriculum, ${ }^{139}$ studies demonstrate significant shortfalls in undergraduate allergy training ${ }^{140}$ considerable scope for improvement in clinicians' awareness and management of allergic rhinitis, ${ }^{99,141}$ and pressure to shorten allergy training programs, ${ }^{141}$ thus threatening standards of care for allergic diseases.

Allergy service provision needs to encompass both primary care and allergy specialists with good collaboration between sectors, ${ }^{112}$ though division of responsibility will vary in different healthcare systems.

\section{Research questions:}

- What is the current state of knowledge about the diagnosis and management of rhinitis in primary care?

- What are the educational needs of primary care clinicians, and how may these be met? Can an educational intervention improve awareness and clinical skills of GPs and improve clinical outcomes in allergic rhinitis?

- What is the optimal balance between generalist care and specialist allergy care in different healthcare systems?

\section{COPD}

COPD is a major public health problem. The prevalence of COPD varies between countries depending on smoking habits, indoor air pollution and the spectrum of age within the population; but globally, COPD was responsible for 3.7 million deaths in $2005,{ }^{5}$ and will rank as the 4th leading cause of death by $2030 .{ }^{142}$

International and national guidelines focus attention on preventing COPD, case finding and/or screening to promote early diagnosis, proactive treatment of symptoms, and attention to supportive and end-of-life care needs. ${ }^{143-148}$ Primary care physicians play a key role in all these aspects of COPD management.

Seven years ago, the IPCRG developed a statement of COPD research needs from the perspective of primary care. ${ }^{4}$ Since then some of the questions identified have been addressed while others have not. The purpose of this section is to update the previous statement and develop a series of research questions pertinent to primary care practice in the new decade.

\subsection{Prevention}

Primary care physicians have a key role in primary prevention, by identifying patients at high risk for COPD and promoting smoking cessation for both individual patients and for communities and populations (see also section 5). ${ }^{149}$ Worldwide, the use of biomass combustion is a major contributor to respiratory illness especially in women. ${ }^{150}$ It is estimated that $40-45 \%$ of the COPD burden in women in developing countries can be attributed to indoor smoke from solid fuels. ${ }^{151}$ The prevention of the unventilated use of biomass fuel in developing countries is complex and requires 
political and societal measures outside the remit of the primary care team. ${ }^{152}$ However, locally-tailored measures to decrease indoor smoke exposure are the subject of an IPCRG / Global Alliance against Chronic Respiratory Diseases (GARD) demonstration project in Vietnam involving nurses and health workers. ${ }^{153}$

Guidelines recommend immunisation against influenza and pneumococcal infection to prevent exacerbations, and many countries offer proactive immunisation programmes.

\section{Research questions:}

- In the context of COPD, what are the key questions that assess smoking history accurately, provide a sensitive and specific assessment of tobacco addiction, and motivation for smoking cessation?

- What is the impact (e.g. on smoking cessation rates, identification of (OPD) of routinely undertaking spirometry in smoking cessation consultations?

- What is the impact of locally-tailored community-level measures to decrease exposure to indoor smoke and reduce harm?

- What organisational approaches (e.g. primary care registers, public health campaigns) are most effective in facilitating good uptake of seasonal flu vaccination?

\subsection{Diagnosis of COPD in primary care}

COPD is both under-diagnosed and over-diagnosed in primary care. ${ }^{27,154}$ Guidelines base the classification of severity on postbronchodilator spirometry, and recommend a threshold-forced expiratory volume in one second/forced vital capacity ( $\mathrm{FEV}_{1} / \mathrm{FVC}$ ) ratio less than 0.7 to confirm a diagnosis of COPD. ${ }^{143-148}$ This fixed ratio cutoff has the advantage of simplicity but does not allow for the natural reduction in the ratio due to lung ageing, thus risking under-diagnosis in younger patients and over-diagnosis in the elderly. ${ }^{35}$ The use of the lower limit of normal (LLN) may improve diagnostic precision but accurate reference ranges are needed in the older patients. ${ }^{155}$

Primary care spirometry has been criticised as being underused, ${ }^{156,157}$ and in many countries is not available outside specialist centres. Concerns about the quality of spirometry ${ }^{158}$ have recently been addressed by a UK document recommending standards for spirometry undertaken in primary care practice. ${ }^{35}$

Validated questionnaires have been developed to support the diagnosis of COPD. ${ }^{159-161}$ Practical experience with these tools is limited and it is not yet clear how such questionnaires can best be used in clinical practice - e.g. to identify patients for spirometry, or to replace spirometry in low income countries where spirometry is not available.

Early diagnosis and subsequent reduction in exposure to smoke could prevent progress to severe disease leading to calls for screening smokers and/or active case finding. ${ }^{159,162}$ International guidelines advise spirometry in all people with respiratory symptoms and/or smoking exposure. ${ }^{143,163,164}$ Such initiatives are likely to be the responsibility of primary care services, but the clinical and cost effectiveness of different strategies (screening or case-finding, questionnaire or spirometry testing, based in primary care or linked with occupational health, health insurance screening) have yet to be established. It is likely that different approaches will be appropriate in different healthcare economies. ${ }^{162,165}$

\section{Research questions:}

Primary care diagnosis:

- What is the best way to identify and diagnose COPD in primary care? Does this incorporate history, age, symptoms and spirometry?

- Can the use of a simple validated questionnaire ${ }^{159-161}$ improve the accurate identification of COPD in different countries (including those without access to spirometry)?

- When a primary care approach to the diagnosis of COPD is applied, what is the diagnostic yield compared to currently accepted diagnostic criteria? ${ }^{143-148}$

Spirometry and assessment:

- What are the essential parameters (e.g. FEV $1 / F V C$ and/or $\mathrm{FEV}_{1} / \mathrm{FEV}_{6}$, inspiratory measurements) of spirometry in primary care?

- What is an appropriate standard of spirometry training for primary care clinicians?

- Is it best to use a fixed ratio or the LLN for the diagnostic $\mathrm{FEV}_{1}$ /FVC threshold? What are the characteristics of patients in the community who are diagnosed with COPD according to the fixed ratio formula and not according to the LLN?

- Should a CXR always be done as part of an initial assessment, regardless of the severity of COPD at diagnosis?

Screening or case finding:

- What is the extent of under- (and over-) diagnosis of COPD in primary care communities in different countries, and to what extent are patients who smoke, (or exposed to burning bio-mass fuels), proactively screened for COPD?

- Which approach to early COPD diagnosis in primary care is underpinned by the strongest clinical and health economic evidence base (questionnaires and/or spirometry, screening or case finding)?

\subsection{Management}

Relief of symptoms, reduction in exacerbation frequency and improved quality of life are the major goals in the management of people with COPD. ${ }^{143-148}$ Recent work suggests that the qualitative difference between 'bad days' and 'exacerbations' may be quantifiable, thus supporting the concept of 'COPD control'166 though the significance of this in clinical practice has yet to be established. The BODE index, ${ }^{167}$ while increasingly important in staging COPD in secondary care practice, involves measurements not routinely available in primary care. The ADO index may be more practical, ${ }^{168}$ and the DOSE index has been developed in primary care and intended for use in routine clinical practice. ${ }^{169}$

A number of validated questionnaires measuring dyspnoea, ${ }^{170,171}$ COPD control, ${ }^{172,173}$ and impact on quality of life $e^{174-176}$ have been 
developed, and although some have been recommended for clinical use none have been validated in this context. Practical considerations (such as length, and mode of administration) will affect feasibility, and floor and ceiling effects will be important in primary care where the population ranges from very mild sub-clinical disease to severely disabling end-stage COPD.

International and national guidelines summarise and make therapeutic recommendations based on the extensive pharmacological and pulmonary rehabilitation evidence base..$^{143,145-148}$ and the IPCRG guidelines for COPD management provide a primary care perspective. ${ }^{144}$ Pragmatic primary care trials with minimum exclusion criteria are needed to assess effectiveness in the diverse populations and healthcare systems in which primary care operates globally.

A range of conditions (e.g. musculoskeletal disorders, heart disease, depression, anxiety, diabetes and osteoporosis/fractures) commonly co-exist with COPD. ${ }^{177-180}$ These co-morbid diseases not only impair and restrict the activity of COPD patients, but also affect the therapeutic options. ${ }^{181,182}$ There is limited evidence to inform primary care clinicians responsible for managing patients with co-morbidity.

\section{Research questions:}

Monitoring COPD:

- Which measurements (spirometry, breathlessness scores, ${ }^{17}$ exercise tolerance, ${ }^{183}$ symptom/control scores, ${ }^{172,173}$ COPD-specific ${ }^{174,176}$ or generic Quality of Life questionnaires ${ }^{175}$ ) are feasible, and provide useful information for routine monitoring and assessing effectiveness of treatment in primary care worldwide?

- Are composite measures (such as the DOSE index ${ }^{169}$ or ADO-index ${ }^{168}$ ) feasible in primary care within a range of health care settings, and valid when compared with established indices (e.g. BODE $\left.{ }^{167}\right)$ ?

Therapeutic management:

- What is the role of low dose theophylline, especially in low income countries where it may be one of the few treatments available?

- How should people with GOLD mild or moderate COPD ${ }^{143}$ be managed in primary care with regard to lifestyle advice (smoking cessation, dietary advice) therapeutic treatment (anti-inflammatory and/or bronchodilators) and physical activity (pulmonary rehabilitation) in order to improve outcomes in different healthcare settings?

Co-morbidities:

- Which are the most prevalent co-morbidities in people with COPD in different countries, and what examinations and tests should be undertaken routinely in order to detect co-morbidities?

- To what extent do primary care clinicians screen people with COPD for depression using appropriate validated screening tools?

- What impact does screening for, and taking action (pharmacological and/or physical activity) to prevent, osteoporosis/fractures have on morbidity?
- What are the optimum treatment regimes (including the impact of polypharmacy) for people with COPD and comorbid conditions such as cardiovascular disease, diabetes or dementia.

\subsection{Management of acute exacerbations}

Despite evidence-based recommendations on the management of acute exacerbations of COPD, ${ }^{143-148}$ there are many unresolved questions for primary care clinicians about definition, prediction, early detection and accurate diagnosis of the cause of exacerbations with the limited diagnostic tools available in the community. ${ }^{184,185}$ Although avoidance of costly admissions is a key policy objective in many healthcare systems, and community-based support may enable safe provision of 'hospital-at-home' care, ${ }^{186}$ a core skill for primary care clinicians in any healthcare setting is recognition of when to refer for specialist care.

\section{Research questions:}

- What impact does immediate access to investigations (e.g. CXR, oxygen saturation, CRP) have on the primary care management of people with acute exacerbations of COPD, and the decision to refer?

- Should choice, dose and duration of treatment (oral corticosteroids, antibiotics) be different for different severity of COPD and severity of exacerbations? Is there a role for inhaled steroids in exacerbations of COPD? ${ }^{187}$

\subsection{Supported self-management}

The importance of empowering self-management is emphasised by guidelines, ${ }^{143-148}$ with some evidence that multidisciplinary programmes can be effective in patients with more severe disease. ${ }^{188}$ The role and format of self-management education for patients with mild or moderate disease in primary care is less clear. ${ }^{189}$ More broadly, it is recognised that people with long-term conditions such as COPD need flexible access to professional support to enable them (and their carers) to manage their own condition. ${ }^{190}$ A 'whole systems' approach to supporting self-care ${ }^{191}$ focuses attention on the patient's understanding of COPD, ${ }^{192}$ the clinician's attitude to patient autonomy, and the accessibility provided by the healthcare organisation.

\section{Research questions:}

- How can clinical services be organised within different healthcare systems to support self-care?

- What is the optimal format of self-management education (including the information content, individualisation of the plan, written or electronic delivery, professional or lay educators) in order to ensure effective communication with patients (often from deprived communities), facilitation of adherence to treatment, and a positive impact on health status?

- How should the self-management education programme be adapted for different severities of disease and/or different healthcare systems? 


\subsection{Supportive and palliative care}

COPD is implicated in about $5 \%$ of deaths. ${ }^{193}$ Despite disabling symptoms (especially breathlessness), complex co-morbidity and social isolation, ${ }^{194-198}$ the needs of people with very severe COPD are rarely addressed adequately. ${ }^{194,199}$ Although 'markers' of a poor prognosis in COPD are well recognised, ${ }^{200}$ the outcome for any individual is unpredictable, ${ }^{201}$ leading to 'prognostic paralysis' on the part of clinicians. ${ }^{202,203}$ Primary care clinicians have an important role in orchestrating proactive supportive care..$^{204}$

\section{Research questions:}

- What is the best palliative treatment for severe dyspnoea?

- How can primary care clinicians overcome the 'paralysis' that results from the uncertain prognosis in order to deliver proactive supportive care?

- How can health and social care services be developed to meet the needs of people with severe COPD within different cultural and healthcare systems?

\subsection{Organisation of COPD care}

The organisation of COPD care will differ between healthcare systems. In some countries, evidence that integrated care improves outcomes $^{205}$ has led to respiratory specialist nurses taking an increasingly important role especially in supporting self-care for those with on-going complex needs, ${ }^{206}$ and providing Hospital-atHome services during acute exacerbations. ${ }^{186}$ Early work suggests that tele-monitoring may have a role in preventing admissions in those with more severe disease. ${ }^{207}$

Pulmonary rehabilitation is acknowledged as an important intervention for people with symptomatic COPD, and recent studies suggest that community programmes can be delivered effectively. ${ }^{208}$

\section{Research questions:}

- What professional skills are required by clinical teams providing integrated care for people with COPD within diverse healthcare systems?

- What are the core requirements for a community-based pulmonary rehabilitation service?

- What is the role of tele-monitoring? Does it reduce admissions and/or improve the quality of life for people with COPD? For which patients, and under what circumstances, does it work best?

- What are the social care needs? Is it possible to integrate social and clinical care?

- What is the role of the voluntary sector? How can the public profile of COPD be raised?

- How can carers and family members be supported?

\section{Tobacco dependence}

Non-communicable diseases (NCDs) caused an estimated 35 million deaths globally in 2005. ${ }^{209}$ This represents around $60 \%$ of deaths worldwide and as much as $80 \%$ of deaths in low- and middleincome countries. Projections for the next decade suggest that this will increase by another $17 \%$. NCDs comprise four major disease areas: cardiovascular disease; cancer; chronic respiratory disease; and diabetes. ${ }^{209}$ Smoking is a major causal factor in all these disease areas. Prevention of smoking in young people and smoking cessation in adults is thus crucial to reducing premature mortality and morbidity, and improving quality of life for those suffering from NCDs. ${ }^{210,211}$

The IPCRG has published guidance for primary care physicians in their central smoking cessation role. ${ }^{149,212}$

\subsection{Prevention}

Preventing young people from starting to smoke is one of the six factors identified by the World Bank that can decrease smoking prevalence. ${ }^{213}$ Increasing the price of cigarettes, ${ }^{214}$ and preventative measures in schools, have been shown to reduce the number of young people who start smoking. ${ }^{215}$ Primary care teams can both campaign for and support societal measures to prevent smoking.

Smoking cessation interventions during pregnancy reduce the proportion of women who continue to smoke and diminish perinatal risk. ${ }^{216}$ Exposure of children to environmental tobacco smoke increases the incidence of respiratory illnesses such as bronchiolitis, otitis media, and frequency of asthma, ${ }^{217,218}$ with consequent excess use of antibiotics. ${ }^{219}$

Smoking is unequally distributed in societies, and increases health inequalities. ${ }^{220}$ Many of those who continue smoking have psychiatric problems or other economic or social problems that maintain their choice to continue smoking.

\section{Research questions:}

Cigarette smoking

- How can primary care clinicians in different countries be made more aware of strategies to prevent smoking in young people and in pregnancy?

- What is the impact of primary care interventions on exposure of children to environmental tobacco smoke and prevention of smoking in young people?

\subsection{National tobacco control policies}

The best results for smoking cessation are achieved with a combination of comprehensive national tobacco control policies and programmes, 221,222 together with individual psychological support and medical therapy. ${ }^{223-225}$

Many countries have public campaigns for smoking cessation, but in most countries the place for smoking cessation is not well defined despite the publication of the WHO Framework Convention on Tobacco control..$^{226}$ Despite clinical and cost effectiveness, many lowand middle-income countries do not make pharmacological treatments for smoking cessation available. ${ }^{227}$ The focus of intervention should be on developing community level education and sustainable non-pharmacological interventions to reduce smoke exposure.

\section{Research questions:}

- How can awareness of the public health importance of tobacco dependence - both among smokers and the primary care professionals - be raised? 


\subsection{Individual smoking cessation support}

The IPCRG has developed guidance specifically for use in primary care internationally, which cites evidence underpinning the provision of brief advice tailored to the person's circumstances and accompanied by appropriate support and treatment. 199,212

As many as $80 \%$ of smokers see their GP once or more per year, ${ }^{228}$ giving the primary healthcare team a unique opportunity to identify smokers, assess their motivation to quit and offer help and support. Time is a barrier to primary care smoking interventions; however, brief advice can increase the number of smokers that make an attempt to quit ${ }^{222,223}$ even when an attempt had not been planned. ${ }^{229,230}$ The impact of brief advice in special populations (e.g. pregnant women, ${ }^{216,231,232}$ adolescents, ${ }^{233}$ patients with mental health problems, ${ }^{234-236)}$ is less clear. Providing support during a quit attempt increases the chance of success up to five-fold. ${ }^{237}$ This can be realistically and effectively provided by primary care clinicians within the context of a routine consultation. ${ }^{237-240}$

Prescribing pharmacological therapy to support a quit attempt significantly increases the chance of success when combined with follow-up and psychological support, 225 with a number needed to treat (NNT) to achieve long term cessation of only 10.241 Nicotine vaccines are under development, and may offer an additional option especially for preventing relapse. ${ }^{242-244}$ Primary care teams can review their patients' progress and offer on-going support, though it is not clear which strategies are most effective in preventing relapse. ${ }^{245}$

\section{Research questions:}

Identifying smokers:

- What questions provide the most sensitive and specific assessment of tobacco dependence and motivation to quit, and of the smoker's individual needs?

- What are the benefits of using questionnaires (e.g. 'willingness to quit', 'addiction to nicotine') in routine clinical practice?

- What psychosocial factors (family, alcoholism, depression etc) affect ability to quit and how may these be overcome?

Brief advice:

- What is the impact of regular and non-judgmental advice to quit on long-term quit rates?

- How can brief advice be used more effectively to increase motivation to quit, and what elements are most efficient for a busy primary care practitioner?

- How can brief advice be implemented in different healthcare systems, and in different clinical (e.g. pregnancy, existing COPD or heart disease, asthma, high risk groups) and psychosocial situations (e.g. those not planning a quit attempt)?

Psychological support:

- What are the most effective models (including primary healthcare or specialist smoking cessation teams) of providing smoking cessation support services in different cultural and/or socioeconomic settings?

\section{Pharmacological treatment:}

- What strategies improve adherence with pharmacotherapeutic agents for smoking cessation?

- What is the clinical and cost effectiveness of nicotine vaccines in assisting smoking cessation and what is their role in primary care populations?

Follow-up:

- What questions, or simple instruments, can be used to assess risk of relapse in primary care consultations?

\subsection{Organisation of services}

Many countries have smoking cessation guidelines with evidencebased recommendations for clinical practice, although implementation of guidelines is poor in many countries. GPs who have undertaken a smoking cessation training programme are more effective in promoting smoking cessation. ${ }^{246}$

Proactive telephone quitlines are effective, ${ }^{247}$ but their availability, GP referral rates, ${ }^{248,249}$ and uptake, varies. ${ }^{250,251}$ Internetbased smoking cessation strategies are in their infancy: while access is an advantage, uptake and utilisation remain problematic. 250,252

\section{Research questions:}

- What models of providing smoking cessation services overcome known barriers (e.g. time, accessibility, expertise) and are acceptable, feasible, effective and costeffective in primary care settings worldwide?

- How can the knowledge of primary healthcare professionals about chronic nicotine addiction be increased (including smoking cessation training programmes)?

- What factors increase the uptake and effectiveness of telephone (and internet) quitline services and how may they be optimised?

\section{Respiratory infections}

Respiratory infections are a very common cause of morbidity and mortality globally and are the leading cause of death in low-income countries. ${ }^{253}$ Although most patients with acute respiratory tract infections (RTIs) self-manage their illness without seeing a doctor, RTIs remain the most common reason for consulting in primary care, accounting for an estimated $15 \%$ of general practice contacts. Most patients are managed within primary care, with the few patients requiring admission representing the 'tip of an iceberg' of illness..$^{254}$

Most human antibiotic use occurs in general practice, ${ }^{254,255}$ the majority of patients consulting with common respiratory tract infections. Antibiotics are of minimal benefit to the large majority of patients with the common cold, ${ }^{256}$ sore throat, ${ }^{257}$ and otitis media. ${ }^{258}$ There may be a role for antibiotics in subgroups of patients with rhinosinusitis and acute bronchitis, ${ }^{259}$ but clinical tools to identify the subgroups which may benefit from antibiotic treatment are largely lacking. Antimicrobial resistance is promoted by inappropriate use of antibiotics. ${ }^{255,260,261}$ Overuse of antibiotics in primary care may lead to increasing resistance both on a local and national level. ${ }^{25,262,263}$ 
However, failing to use antibiotics in cases where they are needed may lead to increased hospitalisation and mortality. ${ }^{264}$ An efficient interface between primary and secondary care is important in the management of respiratory infections. ${ }^{265}$ The paucity of evidence from primary healthcare is of concern, since most respiratory infections are managed primarily by primary care clinicians.

This research agenda will focus on infections of the lower respiratory tract, and aims to highlight questions about the assessment and treatment of lower respiratory tract infections (LRTI) in primary care. Upper respiratory tract infections (including sinus, ear and throat infections) are excluded, as is pulmonary tuberculosis (TB), a very important respiratory infection and a global health problem which has recently been addressed by the WHO. ${ }^{266}$

\subsection{Prevention}

Influenza viruses and bacteria such as Streptococcus pneumoniae and Haemophilus influenza are the commonest pathogens causing respiratory morbidity in the population, ${ }^{267-269}$ and respiratory viral pandemics are a major public health concern. Transmission of LTRI occurs principally in the community, but effective strategies to limit transmission of respiratory infections are incompletely understood.

Vaccinations have an important role in the prevention of respiratory infections. ${ }^{270}$ Extensive vaccination schemes, tailored to local conditions, aim to prevent serious infections and associated complications at an individual level and to reduce the incidence of an infectious disease in a population. Primary care has a key role in the prevention of respiratory infections, although predictors of successful uptake and promotion of vaccination and other prevention strategies are largely lacking. ${ }^{271}$

Primary care clinicians also have a key role in smoking cessation interventions - which are important since smoking is a preventable risk factor for community-acquired pneumonia (CAP) and other LRTIs (see section 5).

\section{Research questions:}

- What are the most effective strategies for prevention and reduction of transmission of LRTIs?

- How can uptake rates for vaccination be improved?

- Is there a role for primary care in smoking cessation, nutritional and other preventative programmes to reduce LRTIs in the community?

\subsection{Diagnosis}

The diagnosis of LRTI and the decision about whether to prescribe antibiotics remains difficult in primary care. Appropriate targeting of treatment relies on prompt and accurate diagnosis. Differentiating bacterial from viral infections is often not possible from the medical history and physical examination alone, suggesting a need for accurate near-patient tests. C-reactive protein (CRP) testing is superior to leucocyte count and erythrocye sedimentation rate (ESR) in diagnosing LRTI, 272-274 and is available as a near-patient test. A recent randomised trial of its use in LRTI showed a clinically significant decrease in antibiotic prescribing with no detrimental effects on clinical recovery. ${ }^{275}$ Although widely used in some countries, its place in routine primary care diagnosis and assessment of RTIs has not been fully established, and validation of these findings in other countries is warranted. The role and use of other diagnostic tests in the management of LRTI (e.g. X-ray, blood tests, microbiology and virology testing) is currently unclear, with an inadequate evidence base guiding their use in primary care. ${ }^{276-278}$

\section{Research questions:}

- How can primary care clinicians differentiate between serious and self-limiting LRTIs?

- How can primary care clinicians reliably identify patients who would benefit from antibiotic therapy? What diagnostic criteria are used in deciding on antibiotic treatment in high-, middle- and low-income countries in primary healthcare settings?

- What investigations for respiratory infections are available in primary care in different countries (eg X-Ray, leucocyte count, CRP, ESR, etc) and how does the use of these ancillary tests affect antibiotic use and clinical outcomes in these countries?

- Is it warranted and feasible to use virology testing in primary care?

6.3. Vulnerable subgroups and co-morbidities

The elderly with respiratory infections are a particularly vulnerable population. Not only do they have a higher risk of developing LRTIS, ${ }^{27,280}$ the increased prevalence of co-morbidity such as cardiopulmonary disease and diabetes puts them at an additional risk of complications. ${ }^{281-}$ ${ }^{283}$ This may explain the increased antibiotic prescription rate for older people with LRTI, ${ }^{284}$ although large trials underpinning the assumption that the elderly will benefit from antibiotic treatment in acute bronchitis are still lacking. ${ }^{285}$ Clinical prediction rules to determine high and low risk elderly patients show promise in assisting primary care clinicians to decide who may be managed at home and who need closer monitoring or hospital care. ${ }^{286,287}$

Morbidity and mortality from respiratory infections are greater in patients with co-morbidities such as COPD, asthma, diabetes, renal failure, alcohol abuse, and immunosuppression. ${ }^{288,289}$ Smokers are prescribed antibiotics more frequently than non-smokers, with no apparent benefit. ${ }^{290,291}$

\section{Research questions:}

- Should management strategies for LRTIs be different in subgroups with various co-morbidities, in smokers, in the elderly, in children, and in pregnant women?

\subsection{Management}

Most patients with a LRTI (even when bacterial infection is confirmed) have a self-limiting condition, but some may go on to develop more serious and life threatening illness such as pneumonia. ${ }^{288}$ Overuse of antibiotics (particularly broad spectrum antibiotics) promotes resistance, ${ }^{25,291,292}$ and does not reduce (or increase) re-consultation rates. ${ }^{293-295}$ Despite interest and research into the effectiveness of 
antibiotics in the treatment of RTIs in the community, ${ }_{1}^{296,297}$ uncertainty persists. Variation in antibiotic prescribing for acute cough is not explained by variation in clinical presentation and is not associated with clinically important differences in recovery. ${ }^{298,299}$

Patients' perceived expectations of antibiotics may drive prescribing. ${ }^{300}$ There is some evidence that the use of patient information strategies and deferred prescription strategies can improve patient satisfaction and reduce inappropriate antibiotic use and re-consultation, but further research is needed. ${ }^{293,300}$ There is limited evidence of OTC treatment of symptoms associated with LRTI. ${ }^{301}$ Cost of treatment may be an issue in lowincome countries. Anti-viral drugs are increasingly available but their use in LRTI is unclear.

\section{Research questions:}

- Which subgroups of patients with LTRIs need antibiotic treatment?

- Which near-patient tests can contribute to cost-effective management of LRTI in primary care by reducing inappropriate antibiotic use without compromising outcomes?

- If antibiotics are used, what are appropriate first-line choices and to what extent do local factors determine antibiotic choice?

- Can deferred prescription strategies reduce antibiotic use without compromising outcomes?

- How should anti-virals be used in primary healthcare?

- Should treatment approaches to LRTI be the same in high-, middle- and low-income countries?

- What is the role of OTC and non-pharmacological therapies in the management of the symptoms of LRTI?

- What is the compliance (adherence and persistence) with different antibiotic treatment regimens? In healthcare systems which allow patients to obtain OTC antibiotics, what is the effect on compliance, on outcomes and on resistance rates? To what extent do people use antibiotic 'left-overs' in the community?

- What determines how long patients wait (delay?) before consulting with their GP?

- Can the use of patient education and information strategies improve patient satisfaction and reduce inappropriate antibiotic use?

- Do primary care clinicians consider the cost of medications to the patient, and does cost and availability of medication affect outcomes?

- Do primary care clinicians follow guidelines such as the British Thoracic Society CAP guidelines ${ }^{288}$ or the SIGN LTRI guideline ${ }^{302}$ in their daily practice? Does the publication of primary care summaries of guidelines ${ }^{303}$ aid implementation of key guideline messages?

- What is the role of primary care in pandemic respiratory infections?

\section{Conclusion}

Respiratory diseases are a public health issue throughout the world, with a high prevalence and morbidity. Primary care has an important role in the management and treatment of respiratory disease and there is a need for research in primary care that is of direct relevance to primary care clinicians and their patients in different countries. International and national guidelines exist, but there is little evidence on the best strategies for implementing recommendations.

- Key asthma questions focus on confirming a diagnosis, assessing control, treatment strategies, encouraging adherence, and empowering self-management. Management of infants and patients with intermittent and/or mild symptoms are a specific challenge.

- Challenges for the care of people with allergic rhinitis include raising the expertise of primary care clinicians, ensuring availability and affordability of suitable self-treatment and prescription medications, and local characterisation of allergens.

- Primary care clinicians have an important role in prevention, identification and management and palliative care of patients with COPD, but practical questions remain about how to deliver this comprehensive agenda in diverse primary care settings.

- The primary care team can and should play a central role in smoking cessation, and outstanding questions focus on mechanisms for encouraging evidence-based primary care cessation services tailored to the needs of different healthcare systems globally.

- Most patients with LTRIs are managed in primary care. There is a need for further epidemiological research, and for evidence to guide the diagnosis and treatment of LRTI, including rational and cost-effective strategies to optimise antibiotic prescribing.

\section{Conflict of interest declaration}

$\mathrm{HP}$ has received fees for lecturing or attending advisory groups from GlaxoSmithKline (GSK), AstraZeneca (AZ), Boeringher Ingelheim (BI), and has been sponsored to attend conferences by $\mathrm{AZ}$ and BI/Pfizer.

DR has received sponsorship from, provided lectures for, or delivered consultancy services to: GSK, AZ, Schering-Plough, MerckSharpeDohme, Chiesi, ALK-Abello, Uriach Pharma, Novartis, BI.

NZ has provided expert advice on smoking cessation education programs to Pfizer Pty Ltd and GSK Australia Pty Ltd and has received support to attend smoking cessation conferences.

AL has received salaries as a speaker and member of advisory boards from many different pharmaceutical companies, and is project leader of the Lung Study which was partly funded through a non-demanding grant from AZ. In his clinical practice he is joint-owner of a DXA bone densitometer.

\section{Contributorship}

The contributors to each section are listed below. The authors who led the discussions and writing of the five sections are highlighted $\left(^{*}\right)$. HP led the editing process and combined the five sections into one overarching document assisted by MT and SW. Asthma

*Karin Lisspers, Uppsala, Sweden; *Björn Ställberg, Uppsala, Sweden; Niels Chavannes, Leiden, The Netherlands; Monica Fletcher, Warwick, UK; Elzbieta KryjRadziszewska, Krakow, Poland; Arnulf Langhammer, Trondheim, Norway; Tan Tze Lee, Singapore; David Price, Aberdeen, UK; Kerstin Romberg, Lund, Sweden; Laura Stacul, Corrientes, Argentina; Marianne Stubbe Ostergaard, Copenhagen, Denmark; Mike Thomas, Aberdeen, UK; Ioanna Tsiligianni, Herakjlion, Crete; Barbara Yawn, Minnesota, USA; Osman Yusuf, Islamabad, Pakistan

Rhinitis

*Osman Yusuf, Islamabad, Pakistan; *Dermot Ryan, Aberdeen, UK; *Elena Latysheva, 
Moscow, Russia; Rui Costa, Porto, Portugal; Thomas Hausen, Essen, Germany; Alan Kaplan, Toronto, Canada; Karin Lisspers, Uppsala, Sweden; Ioanna Tsiligianni, Heraklion, Crete; Barbara Yawn, Minnesota, USA

COPD

* Ioanna Tsiligianni, Heraklion, Crete; *Thys van der Molen, Groningen, The Netherlands; *Arnulf Langhammer, Trondheim, Norway; *Johan Buffels, Leuven, Belgium; *Christos Lionis, Heraklion, Crete; Niels Chavannes, Leiden, The Netherlands; Nicholas Glasgow, Canberra, Australia; Rupert Jones, Plymouth, UK

Tobacco dependence

*Anders Østrem, Oslo, Norway; *Svein Høegh Henrichsen, Oslo, Norway; *John Litt, Adelaide, Australia; *Nick Zwar, Sydney, Australia; *Niels Chavannes, Leiden, The Netherlands; Ioanna Tsiligianni, Herakjlion, Crete; Catalina Panaitescu, Bucharest, Romania; Dimitri Giannopoulos, Patras, Greece; Le thi tuyet Lan, Ho Chi Minh, Vietnam Respiratory infections

*Ioanna Tsiligianni, Herakjlion, Crete; *Jochen WL Cals, Maastricht, The Netherlands; *Mike Thomas, Aberdeen, UK; Jaime Correia de Sousa, Minho, Portugal; Mark Levy, Edinburgh, UK; Christos Lionis, University of Crete, Crete; John MacFarlane, Nottingham, UK; Sarath Paranavitane, Nugegoda, Sri Lanka; Mark Woodhead, Manchester, UK

\section{References}

1. Hummers-Pradier E, Topsever P, Petek Davorina, et al. Research Agenda for General Practice / Family Medicine and Primary Health Care in Europe. Maastricht: European General Practice Research Network, 2009.

2. Herland $\mathrm{K}$, Akelsen J-P, Henning OH, Blermer L. How representative are clinical study patients with asthma or COPD for a larger 'real life' population of patients with obstructive lung disease? Respir Med 2005;99:11-19. http://dx.doi.org/10.1016/ j.rmed.2004.03.026

3. International Primary Care Respiratory Group. Research needs statements. IPCRG Available from http://www.theipcrg.org/resneeds/resneeds.php (accessed February 2010).

4. Price $D$, van der Molen T. The Aberdeen primary care COPD research needs statement. Prim Care Resp J 2001;10:47-50.

5. World Health Organization. Prioritized research agenda for prevention and control of major non-communicable diseases. Geneva: WHO, 2008.

6. Costa DJ, Bousquet PJ, Ryan D, et al. Guidelines for allergic rhinitis need to be used in primary care. Prim Care Resp J 2009;18:250-7. http://dx.doi.org/10.4104/pcri.2009. 00028

7. Masoli M, Fabian D, Holt S, Beasley R. The global burden of asthma: executive summary of the GINA Dissemination Committee report. Allergy 2004;59:469-78. http://dx.doi.org/10.1111/j.1398-9995.2004.00526.x

8. Alwan A, Ross A, Resnikoff S, Mendis S, Cruz AA, Minelli E, from WHO and GARD Executive Committee and Planning Group. Action plan of the Global Alliance against Chronic Respiratory diseases, 2008-2013. Geneva: World Health Organization, 2008.

9. Beaglehole R, Epping-Jordan J, Patel V, et al. Improving the prevention and management of chronic disease in low-income and middle-income countries: a priority for primary health care. Lancet 2008;372:940-9. http://dx.doi.org/10.1016/S0140-6736(08)61404-X

10. Holgate $S$, Bisgaard $H$, Bjermer $L$, et al. The Brussels Declaration: the need for change in asthma management. Eur Respir J 2008;32:1433-42. http://dx.doi.org/ 10.1183/09031936.00053108

11. Haughney J, Palkonen S, Price D, Thomas M, Holgate S. Driving asthma care in Europe: the Brussels Declaration. Prim Care Resp J 2009;18:55-56. http://dx.doi.org/ 10.4104/pcrj.2009.00015

12. Global Initiative for Asthma (GINA) Global Strategy for Asthma Management and Prevention, 2009. Available from: http://www. ginasthma.org (accessed February 2010).

13. National Heart, Lung and Blood Institute. National Asthma Education and Prevention Program. Expert Panel Report 3. Guidelines for the diagnosis and management of asthma 2007. Bethesda: National Institutes of Health, 2007. Available from http://www.nhlbi.nih.gov/guidelines/asthma/asthgdln.htm (accessed February 2010).

14. British Thoracic Society / Scottish Intercollegiate Guidelines Network. British Guideline on the Management of Asthma. Thorax 2008;63(Suppl 4):iv1-121. http://dx.doi.org/ 10.1136/thx.2008.097741

15. The AGREE Collaboration. The Appraisal of Guidelines for Research \& Evaluation instrument. London: The AGREE Research Trust, 2001. Available from http://www.agreetrust.org (accessed February 2010)

16. Scottish Intercollegiate Guideline Network. SIGN 50: A guideline developer's handbook. Edinburgh: SIGN 2008. Available from http://www.sign.ac.uk (accessed February 2010)

17. Levy $M$, Fletcher $M$, Price $D$ et al. International Primary Care Respiratory Group (IPCRG) Guidelines: Diagnosis of respiratory diseases in primary care. Prim Care Resp J 2006;15:20-34. http://dx.doi.org/10.1016/j.pcrj.2005.10.004

18. Wahn HU. Strategies for atopy prevention. J Nutr 2008;138:1770S-1772S.

19. Jaakkola MS, Piipari R, Jaakkola N, Jaakkola JJ. Environmental tobacco smoke and adult-onset asthma: a population-based incident case-control study. Am J Public Health 2003;93:205560. http://dx.doi.org/10.2105/AJPH.93.12.2055

20. Department of Health. Report of the Scientific Committee on Tobacco and Health. London:
HMSO, 1998

21. Thomson NC. Smokers with asthma: what are the management options? Am J Respir Crit Care Med 2007; 175:749-50.

22. Tarlo SM, Liss GM. Occupational asthma: an approach to diagnosis and management. CMA 2003;168:867-71. http://dx.doi.org/10.1164/rccm.200701-017ED

23. van Schayck $C P$, Chavannes $\mathrm{NH}$. Detection of asthma and chronic obstructive pulmonary disease in primary care. Eur Respir J 2003;21(Suppl39):16s-22s. http://dx.doi.org/10.1183/09031936.03.00040403

24. Van Weel C. Underdiagnosis of asthma and COPD: is the general practitioner to blame? Monaldi Arch Chest Dis 2002;57:65-8.

25. Montnemery P, Hansson L, Lanke J, et al. Accuracy of a first diagnosis of asthma in primary health care. Fam Pract 2002;19:365-8. http://dx.doi.org/10.1093/fampra/19.4.365

26. van Schayck $C P$, van Der Heijden FM, van Den Boom G, Tirimanna PR, van Herwaarden $C L$. Underdiagnosis of asthma: is the doctor or the patient to blame? The DIMCA project. Thorax 2000;55:562-5. http://dx.doi.org/10.1136/thorax.55.7.562

27. Tinkelman DG, Price DB, Nordyke RJ, Halbert RJ. Misdiagnosis of COPD and Asthma in Primary Care Patients 40 Years of Age and Over. J Asthma 2006;43:75-80. http://dx.doi.org/10.1080/02770900500448738

28. Stanbrook MB, Kaplan A. The error of not measuring asthma. CMAJ 2008;179:1121-31 http://dx.doi.org/10.1503/cmaj.081665.

29. Bush A. Diagnosis of asthma in children under five. Prim Care Resp J 2007;16:7-15. http://dx.doi.org/10.3132/pcri.2007.00001

30. Rastogi D, Gupta S, Kapoor R. Comparison of Asthma Knowledge, Management, and Psychological Burden among Parents of Asthmatic Children From Rural and Urban Neighborhoods in India_J Asthma 2009;46:911-15. http://dx.doi.org/10.3109/ 02770900903191323

31. Averame $G$, Bonavia $M$, Ferri $P$, et al. Office spirometry can improve the diagnosis of obstructive airway disease in primary care setting. Respir Med 2009;103:866-72. http://dx.doi.org/10.1016/j.rmed.2008.12.017

32. Cerveri I, Corsico AG, Accordini S, et al. What defines airflow obstruction in asthma? Eur Respir / 2009;34:568-73. http://dx.doi.org/10.1183/09031936.00172908

33. Brand PLP, Baraldi $E$, Bisgaard $H$, et al. Definition, assessment and treatment of wheezing disorders in preschool children: an evidence-based approach. Eur Respir J 2008;32:10961110. http://dx.doi.org/10.1183/09031936.00002108

34. Schultz A, Devadason S,Savenije O, et al. The transient value of classifying preschool wheeze into episodic viral wheeze and multiple trigger wheeze. Acta Paediatr 2010;99:56-60.

35. Levy ML, Quanjer PH, Booker R, et al. Diagnostic Spirometry in Primary Care. Proposed standards for general practice compliant with American Thoracic Society and European Respiratory Society Recommendations. Prim Care Resp J 2009;18:130-47. http://dx.doi.org/10.4104/pcrj.2009.00054

36. van der Molen T, Østrem A, Stallberg B, Østergaard MS, Singh RB. International Primary Care Respiratory Group (IPCRG) Guidelines: management of asthma. Prim Care Resp J 2006;15:3547. http://dx.doi.org/10.1016/j.pcrj.2005.11.001

37. Reddel HK, Taylor DR, Bateman ED, et al. An Official American Thoracic Society / European Respiratory Society Statement: Asthma Control and Exacerbations: Standardizing Endpoints for Clinical Asthma Trials and Clinical Practice. Am J Respir Crit Care Med 2009;180:59-99. http://dx.doi.org/10.1164/rccm.200801-060ST

38. Haughney J, Barnes G, Partridge M, Cleland J. The Living \& Breathing study: a study of patients' views of asthma and its treatment. Prim Care Resp J 2004;13:28-35 http://dx.doi.org/10.1016/j.pcrj.2003.11.007

39. Rabe KF, Vermeire PA, Soriano JB, Maier WC. Clinical management of asthma in 1999: the Asthma Insights and Reality in Europe (AIRE) study. Eur Respir J 2000;16:802-07.

40. Haughney J, Price D, Kaplan A, et al. Achieving asthma control in practice: Understanding the reasons for poor control. Respir Med 2008;102:1681-93. http://dx.doi.org/10.1016/j.rmed.2008.08.003

41. Horne R, Price D, Cleland J, et al. Can asthma control be improved by understanding the patient's perspective? BMC Pulm Med 2007;7:8. http://dx.doi.org/10.1186/1471-2466-7-8

42. Pinnock $\mathrm{H}$, Fletcher $\mathrm{M}$, Holmes $\mathrm{S}$, et al. Setting the standard for routine asthma consultations: a discussion of the aims, process and outcomes of reviewing people with asthma in primary care. Prim Care Resp J 2010;19(1):75-83. http://dx.doi.org/ 10.4104/pcri.2010.00006

43. Taylor DR, Bateman ED, Boulet $L P$, et al. A new perspective on concepts of asthma severity and control. Eur Respir J 2008;32:545-54. http://dx.doi.org/10.1183/09031936.00155307

44. Humbert M, Holgate S, Boulet LP, Bousquet J. Asthma control or severity: that is the question. Allergy 2007;62:95-101. http://dx.doi.org/10.1111/.1398-9995.2006.01308.x

45. Braganza S, Sharif I, Ozuah PO. Documenting asthma severity: do we get it right? J Asthma 2003;40:661-5. http://dx.doi.org/10.1081/JAS-120019037

46. International Primary Care Respiratory Group. The IPCRG Users' Guide to currently available asthma control tools. Aberdeen: IPCRG, 2006. Available from http://www.theipcrg.org (accessed February 2010)

47. Nathan RA, Sorkness CA, Kosinski M, et al. Development of the asthma control test: a survey for assessing asthma control. J Allergy Clin Immunol 2004;113:59-65. http://dx.doi.org/10.1016/j.jaci.2003.09.008

48. Schatz M, Sorkness CA, Li JT, et al. Asthma Control Test: reliability, validity, and responsiveness in patients not previously followed by asthma specialists. I Allergy Clin Immunol 
2006;117:549-56. http://dx.doi.org/10.1016/j.jaci.2006.01.011

49. Thomas M, Kay S, Pike J, et al. The Asthma Control Test TM (ACT) as a predictor of GINA guideline-defined asthma control: analysis of a multinational cross-sectional survey. Prim Care Resp J 2009;18:41-49.

50. Juniper EF, O'Byrne PM, Guyatt GH, Ferrie PJ, King DR. Development and validation of a questionnaire to measure asthma control. Eur Respir J 1999;14:902-07

51. Juniper EF, Svensson K, Mork AC, Stahl E. Measurement properties and interpretation of three shortened versions of the asthma control questionnaire. Respir Med 2005;99:553-8 http://dx.doi.org/10.1016/..rmed.2004.10.008.

52. Juniper EF, Bousquet J, Abetz L, Bateman ED. Identifying 'well-controlled' and 'not wellcontrolled' asthma using the Asthma Control Questionnaire. Respir Med 2006;100:616-21 http://dx.doi.org/10.1016/j.rmed.2005.08.012

53. Pearson MG, Bucknall CE, editors. Measuring clinical outcome in asthma: a patient-focused approach. London: Royal College of Physicians, 1999.

54. Thomas M, Gruffydd-Jones K, Stonham C, Ward S, Macfarlane T. Assessing asthma control in routine clinical practice: use of the Royal College of Physicians '3 Questions'. Prim Care Resp J 2009;18:83-88

55. Bousquet J, Khaltaev N, Cruz AA, and the ARIA group in collaboration with the World Health Organization, GA(2)LEN and AllerGen. Allergic Rhinitis and its Impact on Asthma (ARIA) 2008 update. Allergy 2008;63(Suppl 86):8-160. http://dx.doi.org/10.1111/j.13989995.2007.01620.x

56. Orsini L, Limpa-Amara S, Crown WH, Stanford RH, Kamal K, Asthma hospitalization risk and cost for patients treated with fluticasone propionate vs Montelukast. Ann Allergy Asthma Immuno/ 2004;5:523-9. http://dx.doi.org/10.1016/S1081-1206(10)61759-0

57. Ducharme FM, Lasserson TJ, Cates CJ. Long-acting beta2-agonists versus anti-leukotrienes as add-on therapy to inhaled corticosteroids for chronic asthma. Cochrane Database of Systematic Reviews 2006, Issue 4. Art. No.: CD003137. http://dx.doi.org/ 10.1002/14651858.CD003137.pub3

58. Brocklebank D, Ram F, Wright J, et al. Comparison of the effectiveness of inhaler devices in asthma and chronic obstructive airways disease: a systematic review of the literature. Health Technol Assess 2001;5:1-149.

59. Foster JM, Sanderman R, van der Molen T, MuellerT, van Sonderen E. Personality Influences the Reporting of Side Effects of Inhaled Corticosteroids in Asthma Patients. J Asthma 2008;45:664-9. http://dx.doi.org/10.1080/02770900802127022

60. Jones C, Santanello NC, Boccuzzi SJ, Wogen J, Strub P, Nelsen LM. Adherence to prescribed treatment for asthma: evidence from pharmacy benefits data. J Asthma 2003;40:93-101. http://dx.doi.org/10.1081/JAS-120017212

61. Neville RG, Clark RC, Hoskins G, Smith B. for the General Practitioners in Asthma Group: National asthma attack audit 1991-2. BMJ 1993;306:559-562. http://dx.doi.org/ 10.1136/bmi.306.6877.559

62. Neville RG, Hoskins G, Smith B, Clark RA. How general practitioners manage acute asthma attacks. Thorax 1997;52:153-156. http://dx.doi.org/10.1136/thx.52.2.153

63. Pinnock $H$, Johnson A, Young P, Martin N. Are doctors still failing to assess and treat asthma attacks? An audit of the management of acute attacks in a health district. Respir Med 1999;93:397-401. http://dx.doi.org/10.1053/rmed.1999.0575

64. Guittet L, Blaisdell CJ, Just J, Rosencher L, Valleron A-J, Flahault A. Management of acute asthma exacerbations by general practitioners: a cross-sectional observational survey. $\mathrm{Br} J$ Gen Pract 2004;54:759-64.

65. Gibson PG, Powell H, Coughlan J, et al. Self-management education and regular practitioner review for adults with asthma. The Cochrane Database of Systematic Reviews 2002, Issue 3 Art. No.: CD001117. http://dx.doi.org/10.1002/14651858.CD001117

66. Powell H, Gibson PG. Options for self-management education for adults with asthma. The Cochrane Database of Systematic Reviews 2002, Issue 3. Art. No.: CD004107. http://dx.doi.org/10.1002/14651858.CD004107

67. Wolf FM, Guevara JP, Grum CM, Clark NM, Cates CJ. Educational interventions for asthma in children. The Cochrane Database of Systematic Reviews 2002, Issue 4. Art. No.: CD000326. DOI: 10.1002/14651858.CD000326

68. Price $D$, Wolfe $S$. Delivery of asthma care: patient's use of and views on healthcare services, as determined from a nationwide interview survey. Asthma J 2000;5:141-4.

69. Wiener-Ogilvie S, Pinnock H, Huby G, Sheikh A, Partridge MR, Gillies J, Do practices comply with key recommendations of the British Asthma Guideline, and if not, why not? Prim Care Resp J 2007;16:369-77. http://dx.doi.org/10.3132/pcrj.2007.00074

70. Moudgil H, Marshall T, Honeybourne D. Asthma education and quality of life in the community: a randomised controlled study to evaluate the impact on white European and Indian subcontinent ethnic groups from socioeconomically deprived areas in Birmingham, UK. Thorax 2000;55:177-83. http://dx.doi.org/10.1136/thorax.55.3.177

71. Guendelman S, Meade K, Benson M, Chen Y, Samuels S. Improving Asthma Outcomes and Selfmanagement Behaviors of Inner-city Children. Arch Pediatr Adolesc Med 2002;156:114-20.

72. Thoonen BPA, Schermer TRJ, van den Boom G, et al. Self-management of asthma in general practice, asthma control and quality of life: a randomised controlled trial. Thorax 2003;58:3036. http://dx.doi.org/10.1136/thorax.58.1.30

73. Glasgow NJ, Ponsonby A-L, Yates R, Beilby J, Dugdale P. Proactive asthma care in childhood: general practice based randomised controlled trial. BMJ 2003;327:659-65. http://dx.doi.org/10.1136/bmj.327.7416.659
74. Ring N, Malcolm C, Wyke S, et al. Promoting the use of Personal Asthma Action Plans: a systematic review. Prim Care Resp J 2007;16:271-83. http://dx.doi.org/ 10.3132/pcrj.2007.00049

75. Kemple T, Rogers C. A mailed personalised self-management plan improves attendance and increases patients' understanding of asthma. Prim Care Resp J 2003;12:110-14.

76. Delaronde S, Peruccio DL, Bauer BJ. Improving asthma treatment in a managed care population. Am J Managed Care 2005;11:361-8.

77. Feifer RA, Verbrugge RR, Khalid M, Levin R, O'Keefe GB, Aubert RE. Improvements in asthma pharmacotherapy and self-management: An example of a population-based disease management program. Dis Manage Health Outcomes 2004;12:93-102. http://dx.doi.org/10.2165/00115677-200412020-00003

78. Jones A, Fay JK, Ram FSF. Primary care based clinics for asthma. Cochrane Database of Systematic Reviews 2002, Issue 1. Art. No.: CD003533. http://dx.doi.org/ 10.1002/14651858.CD003533.

79. Pinnock $H$, Bawden $R$, Proctor $S$, et al. Accessibility, acceptability and effectiveness of telephone reviews for asthma in primary care: randomised controlled trial. BM 2003;326:477-9. http://dx.doi.org/10.1136/bmj.326.7387.477

80. Gruffydd-Jones K, Hollinghurst S, Ward S, Taylor G. Targeted routine asthma care in genera using telephone triage. Br J Gen Pract 2005;55:918-23.

81. Pinnock H, Adlem L, Gaskin S, Harris J, Snellgrove C, Sheikh A. Accessibility, clinica effectiveness and practice costs of providing a telephone option for routine asthma reviews: controlled implementation study. Br J Gen Pract 2007:57:714-22.

82. Pinnock $H$, Slack $R$, Pagliari $C$, Price $D$, Sheikh A. Understanding the potential role of mobile phone based monitoring on asthma self-management: qualitative study. Clin Exp Allergy 2007;3:794-802. http://dx.doi.org/10.1111/j.1365-2222.2007.02708.x

83. Pinnock $H$, Snellgrove $C$, Madden $V$, Sheikh A. Telephone or surgery asthma reviews? Preferences of participants in a primary care randomised controlled trial. Prim Care Resp 2005; 14:42-46.

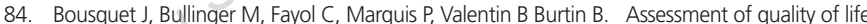
in patients with perennial rhinitis with the French version of the SF-36 health status questionnaire. J Allergy Clin Immunol 1994;94:182-8. http://dx.doi.org/10.1016/00916749(94)90038-8

85. Settipane RJ; Hagy GW; Settipane GA. Long-term risk factors for developing asthma and allergic rhinitis: a 23-year follow-up study of college students. Allergy Proc 1994;15:21-5 http://dx.doi.org/10.2500/108854194778816634

86. Meltzer EO: The prevalence and medical and economic impact of allergic rhinitis in the United States. J Allergy Clin Immunol 1997;99:S805-S828

87. Bousquet PJ, Godard P, Daures JP. The public health implications of asthma. Bulletin of the World Health Organization 2005;83:548-54.

88. Bousquet J, Bachert C, Canonica G, et al on behalf of the extended GA2LEN, World Allergy Organization and ARIA Study Group. Unmet needs in severe chronic upper airway disease (SCUAD). J Allergy Clin Immunol 2009;124:428-33. http://dx.doi.org/10.1016/j.jaci.2009.06.027

89. Min YG, Jung HW, Kim SK, et al. Prevalence and risk factors for perennial allergic rhinitis in Korea: results of a nationwide survey. Clin Otolaryngol Allied Sciences 2003;22:139-44 http://dx.doi.org/10.1046/j.1365-2273.1997.00879.x

90. Saleh HA, Durham SR. Clinical Review: Perennial rhinitis. BMJ 2007:335:502-07. http://dx.doi.org/10.1136/bmj.39304.678194.AE

91. Stewart MG. Identification and management of undiagnosed and undertreated allergic rhinitis in adults and children. Clin Exp Allergy 2008;38:751-60. http://dx.doi.org/10.1111/j.13652222.2008.02937.x

92. Skoner DP. Allergic rhinitis: definition, epidemiology, pathophysiology, detection, and diagnosis. J Allergy Clin Immunology 2001;108(Suppl1):S2-8 http://dx.doi.org/10.1067/mai.2001.115569

93. Bauchau $V$, Durham SR. Prevalence and rate of diagnosis of allergic rhinitis in Europe. Eur Respir J 2004;24:758-64. http://dx.doi.org/10.1183/09031936.04.00013904

94. Didier A, Chanal I, Klossek JM, Mathieu J. La rhinite allergique: le point de vue du patient. Revue Française Allergologie 1999;39:171-85.

95. Scadding G, Richards DH, Price MJ. Patient and physician perspectives on the impact and management of perennial and seasonal allergic rhinitis. Clin Otolaryngol 2000;25:551-55. http://dx.doi.org/10.1046/j.1365-2273.2000.00417.x

96. Ryan D, van Weel C, Bousquet J, et al. Primary care: the cornerstone of diagnosis of allergic rhinitis. Allergy 2008;63:981-9. http://dx.doi.org/10.1111/j.1398-9995.2008.01653.x

97. van Cauwenberge $P$, van Hoecke $H$, Kardos $P$, Price D, Waserman S. The current burden of allergic rhinitis amongst primary care practitioners and its impact on patient management. Prim Care Resp J 2009;18:27-33.

98. Bousquet J, Neukirch F, Bousquet PJ, et al. Severity and impairment of allergic rhinitis in patients consulting in primary care. I Allergy Clin Immunol 2006:117:158-62. http://dx.doi.org/10.1016/j.jaci.2005.09.047

99. Ryan D, Grant-Casey J, Scadding G, Pereira S, Pinnock H, Sheikh A. Management of allergic rhinitis in UK primary care: baseline audit. Prim Care Resp J 2005;14:204-09. http://dx.doi.org/10.1016/j.pcrj.2005.03.009

100. Annesie-Maesano I, Didier A, Klossek M, Chanal I, Moreau D, Bosquet J. The score for allergic rhinitis (SFAR); a simple and valid assessment method in population studies. Allergy 
2002;57:107-14

100. Annesie-Maesano I, Didier A, Klossek M, Chanal I, Moreau D, Bosquet J. The score for allergic rhinitis (SFAR); a simple and valid assessment method in population studies. Allergy 2002; $57: 107-14$

http://dx.doi.org/10.1034/j.1398-9995.2002.103170.x

101. Shaaban $R$, Zureik $M$, Soussan $D$, et al. Rhinitis and onset of asthma: a longitudinal population-based study. Lancet 2008;372:1049-057. http://dx.doi.org/10.1016/S01406736(08)61446-4

102. Mahesh PA, Vedanthan PK, Holla AD, Jayaraj $B_{1}$. Prabhakar A. . Time Interval and the Factors Associated with the Development of Asthma in Patients with Allergic Rhinitis. Lung 2009 published on-line. http://dx.doi.org/10.1007/s00408-009-9179-x.

103. Clatworthy J, Price D, Ryan D, Haughney J, Horne R. The value of self-report assessment of adherence, rhinitis and smoking in relation to asthma control. Prim Care Resp J 2009;18:30005. http://dx.doi.org/10.4104/pcrj.2009.00037

104. Thomas M, Kocevar VS, Zhang Q, Yin DD, Price D. Asthma-related health care resource use among asthmatic children with and without concomitant allergic rhinitis. Pediatrics 2005;115:129-34.

105. Koga T, Matsuse H, Kohrogi H, Kohno S, Aizawa H. Impact of Nasal Condition on Selfassessed Disease Control and Treatment Satisfaction in Patients with Asthma Complicated by Allergic Rhinitis. Allergol Int 2007;56:427-31. http://dx.doi.org/10.2332/allergolint.0-06-477

106. Stelmach $R$, do Patrocinio TNM, Ribeiro M, Cukier A. Effect of treating allergic rhinitis with corticosteroids in patients with mild-to-moderate persistent asthma. Chest 2005;128:3140-7. http://dx.doi.org/10.1378/chest.128.5.3140

107. Price DB, Swern A, Tozzi CA, Philip G, Polos P. Effect of montelukast on lung function in asthma patients with allergic rhinitis: analysis from the COMPACT trial. Allergy 2006;61:1153-1153. http://dx.doi.org/10.1111/j.1398-9995.2006.01007.x

108. Nogueira-Silva L, Martins SV, Cruz-Correia R, et al. Control of allergic rhinitis and asthma test - a formal approach to the development of a measuring tool. Respiratory Research 2009;10:52 http://dx.doi.org/10.1186/1465-9921-10-52

109. Price D, Bond C, Bouchard J, et al. International Primary Care Respiratory Group (IPCRG) Guidelines: Management of allergic rhinitis. Prim Care Resp J 2006;15:58-70.

110. Scadding GK, Durham SR, Mirakian R, et al. BSACl guidelines for the management of allergic and non-allergic rhinitis. Clin Exp Allergy 2008;38:19-42

111. Thomas M, Yawn BP, Price D, Lund V, Mullol J, Fokkens W, EPOS Primary Care Guidelines: European Position Paper on the Primary Care Diagnosis and Management of Rhinosinusitis and Nasal Polyps 2007 - a summary. Prim Care Resp J 2008;17:79-89. http://dx.doi.org/10.3132/pcrj.2008.00029

112. Ryan D, Levy M, Morris A, Sheikh A, Walker S. Management of allergic problems in primary care: time for a rethink? Prim Care Resp J 2005;14:195-203. http://dx.doi.org/10.1016/.jpcrj.2005.01.003

113. Wallace DV, Dykewicz MS, Bernstein DI, et al. The Diagnosis and Management of Rhinitis: An Updated Practice Parameter. I Allergy Clin Immunol 2008;122:S1-S84. http://dx.doi.org/10.1016/j.jaci.2008.06.003

114. Sheikh A, Hurwitz B, Shehata YA. House dust mite avoidance measures for perennial allergic rhinitis. Cochrane Database of Systematic Reviews 2007, Issue 1. Art. No.: CD001563. http://dx.doi.org/10.1002/14651858.CD001563.pub2

115. Dykewicz MS, Fineman S, Skoner DP, et al. Diagnosis and management of rhinitis: complete guidelines of the Joint Task Force on Practice Parameters in Allergy, Asthma and Immunology. Ann Allergy Asthma Immunol 1998;81:478-518. http://dx.doi.org/10.1016/S10811206(10)63155-9

116. van Schayck O, Maas T, Koper J, Knottnerus AJA, Sheikh A. Is there any role for allergen avoidance in the primary prevention of childhood asthma? I Allergy Clin Immunol 2007;119:1323-8. http://dx.doi.org/10.1016/j.jaci.2007.02.024

117. Ragab SM, Lund VJ, Scadding G. Evaluation of the medical and surgical treatment of chronic rhinosinusitis: a prospective, randomised, controlled trial. Laryngoscope 2004;114:923-30. http://dx.doi.org/10.1097/00005537-200405000-00027

118. Spector SL, Toshener D, Gay I, Rosenman E. Beneficial effects of propylene and polyethylene glycol and saline in the treatment of perennial rhinitis. Clin Allergy 1982;12:187-96. http://dx.doi.org/10.1111/j.1365-2222.1982.tb01638.x

119. Taccariello M, Parikh A, Darby $Y$, Scadding G. Nasal douching as a valuable adjunct in the management of chronic rhinosinusitis. Rhinology 1999;37:29-32.

120. Passali D, Damiani V, Passali FM,Passali GC, Bellussi L. Atomized nasal douche vs nasal lavage in acute viral rhinitis. Arch Otolaryngol Head Neck Surg 2005;131:788-90. http://dx.doi.org/10.1001/archotol.131.9.788

121. Koreck Al, Csoma Z, Bodai L, et al. Rhinophototherapy: a new therapeutic tool for the management of allergic rhinitis. J Allergy Clin Immunol 2005;115:541-7. http://dx.doi.org/10.1016/j.jaci.2004.11.005

122. O'Meara TJ, Sercombe JK, Morgan G, Reddel HK, Xuan W, Tovey ER. The reduction of rhinitis symptoms by nasal filters during natural exposure to ragweed and grass pollen. Allergy 2005;60:529-32. http://dx.doi.org/10.1111/j.1398-9995.2005.00741.x

123. Schwetz S, Olze H, Melchisedech S, Grigorov A, Latza R. Efficacy of pollen blocker cream in the treatment of allergic rhinitis. Arch Otolaryngol Head Neck Surg 2004;130:979-84. http://dx.doi.org/10.1001/archotol.130.8.979

124. Emberlin JC, Lewis RA. A double blind, placebo controlled trial of inert cellulose powder for the relief of symptoms of hay fever in adults. Curr Med Res Opin 2006;22:275-85. http://dx.doi.org/10.1185/030079906X80440

125. Gotoh M, Okubo K, Okuda M. Inhibitory effects of facemasks and eyeglasses on invasion of pollen particles in the nose and eye: a clinical study. Rhinology 2005;43:266-70.

126. Giovannini M, Agostoni C, Riva E, et al. A randomized prospective double blind controlled trial on effects of long-term consumption of fermented milk containing Lactobacillus casei in pre-school children with allergic asthma and/or rhinitis. Pediatr Res 2007;62:215-20. http://dx.doi.org/10.1203/PDR.0b013e3180a76d94

127. Tamura M, Shikina T, Morihana T, et al. Effects of probiotics on allergic rhinitis induced by Japanese cedar pollen: randomized double blind, placebo-controlled clinical trial. Int Arch Allergy Immunol 2007;143:75-82. http://dx.doi.org/10.1159/000098318

128. Plaut M, Valentine MD. Allergic Rhinitis. New Engl J Med 2005;353:1934-44. http://dx.doi.org/10.1056/NEJMcp044141

129. van Cauwenberge P, Bachert C, Passalacqua G, et al. Consensus statement on the treatment of allergic rhinitis: European Academy of Allergology and Clinical Immunology. Allergy 2000;55:116-34. http://dx.doi.org/10.1034/j.1398-9995.2000.00526.x

130. Ostergaard MS, Ostrem A, Soderstrom M. Hay fever and a single intramuscular injection of corticosteroid: a systematic review. Prim Care Resp J 2005;14:124-3. http://dx.doi.org/10.1016/j.pcrj.2004.08.001

131. Mirzai R, Chang C, Greenspan A, Gershwin ME. The pathogenesis of osteonecrosis and the relationships to corticosteroids. J Asthma 1999;36:77-95. http://dx.doi.org/ 10.3109/02770909909065152

132. Canonica W, Bousquet J, Casale RF et al. Sublingual Immunotherapy: World Allergy Organisation Position Paper 2009. Allergy 2009;64(suppl 91):1-59. http://dx.doi.org/10.1111/j.1398-9995.2009.02309.x

133. Howard ME, Desai AV, Grunstein RR, et al. Sleepiness, Sleep-disordered Breathing, and Accident Risk Factors in Commercial Vehicle Drivers. Am J Respir Crit Care Med 2004;170:1014-21. http://dx.doi.org/10.1164/rccm.200312-17820C

134. Church MK, Maurer M, Simons FER, Bindslev-Jensen C, van Cauwenberge $P$, Bousquet J, Holgate ST, Zuberbier T. Risk of first-generation H1-antihistamines: a GA2LEN position paper Allergy 2010; http://dx.doi.org/10.1111/j.1398-9995.2009.02325.x

135. Walker $S$, Khan-Wasti $S$, Fletcher $M$ et al. Seasonal allergic rhinitis is associated with a detrimental effect on examination performance in United Kingdom teenagers: Case-contro study. I Allergy Clin Immunol 2007;120:381-387. http://dx.doi.org/10.1016/j.jaci.2007.03.034

136. Levy ML, Walker S, Woods A, Sheikh A. Service evaluation of a UK primary care-based allergy clinic: quality improvement report. Prim Care Resp J 2009;18:313-19. http://dx.doi.org/10.4104/pcri.2009.00042

137. Pinnock $H$, Sheikh A. Meeting the information needs of patients with allergic disorders: partnership is the key. Clin Exp Allergy 2004;34:1333-5. http://dx.doi.org/ 10.1111/j.13652222.2004.02065.x

138. Green RJ, Davis G, Price D. Concerns of patients with allergic rhinitis: the Allergic Rhinitis Care Programme in South Africa. Prim Care Resp J 2007:16:299-303. http://dx.doi.org/10.3132/pcri.2007.00062

139. Potter PC, Warner JO, Pawankar R et al. on behalf of the WAO Specialty and Training Counci Recommendations for Competency in Allergy Training for Undergraduates Qualifying as Medical Practitioners: A Position Paper of the World Allergy Organization World Allergy Organization Journal 2009;2:150-4.

140. Shehata $Y$, Ross $M$, Sheikh A. Undergraduate allergy teaching in a UK medical school: comparison of the described and delivered curriculum. Prim Care Resp J 2007;16:16-21. http://dx.doi.org/10.3132/pcri.2007.00004

141. Baptist, Alan P. Baldwin, James L. Physician attitudes, opinions, and referral patterns: comparisons of those who have and have not taken an allergy/immunology rotation. Ann Allergy Asthma Immunol 2004;93:227-3. http://dx.doi.org/10.1016/S1081-1206(10)61492-

142. Mathers CD, Loncar D. Updated projections of global mortality and burden of disease, 2002 2030: data sources, methods and results. Geneva; WHO 2005.

143. Global Initiative for Chronic Obstructive Lung Disease (GOLD), Global strategy for diagnosis, management, and prevention of COPD: updated 2009. Available from: www.goldcopd.com (accessed February 2010)

144. Bellamy D, Bouchard J, Henrichsen S, et al. International Primary Care Respiratory Group (IPCRG) guidelines: management of chronic obstructive pulmonary disease (COPD). Prim Care Resp J 2006;15:48-57. http://dx.doi.org/10.1016/j.pcrj.2005.11.003

145. National Institute for Clinical Excellence. National clinical guideline management of chronic obstructive pulmonary disease in adults in primary and secondary care. Thorax 2004;59(Suppl1):S1-232.

146. McKenzie DK, Abramson M, Crockett AJ, et al. on behalf of The Australian Lung Foundation. The COPD-X Plan: Australian and New Zealand Guidelines for the management of Chronic Obstructive Pulmonary Disease 2009. Available from www.copdx.org.au (Accessed February 2010).

147. Smeele IJM, Van Weel C, Van Schayck CP, et al. Nederlands Huisartsen Genootschap (NHG): Standaard COPD. Huisarts Wet 2007; 50:362-79.

148. American Thoracic Society, European Respiratory Society. Standards for the diagnosis and management of patients with COPD 2004. Available from http://www.ersnet.org (accesed 
February 2010)

149. van Schayck OC, Pinnock $H$, Ostrem $A$, et al. IPCRG Consensus statement: tackling the smoking epidemic - practical guidance for primary care. Prim Care Resp J 2008;17:185-93. http://dx.doi.org/10.3132/pcri.2008.00060

150. Smith KR, Mehta S, Maeusezahl-Feuz M. Indoor air pollution from household use of solid fuels. in Comparative Quantification of Health Risks Volume 2. Eds: Ezzati M, Lopez AD, Rodgers A, Murray CJL. Geneva; World Health Organization 200

151. World Health Organization. World Health Report 2002: Reducing Risks, Promoting Healthy Life. Geneva: WHO, 2002

152. World Health Organization Evaluating household energy and health interventions: a catalogue of methods. Geneva: WHO, 2008

153. Lan L, Vinh N, Chavannes N. GARD Vietnam Demonstration Project IPCRG 2009. http://www.theipcrg.org/news/gardproposalvietnamdemoproject.doc (accessed February 2010)

154. Bednarek M, Maciejewski J, Wozniak M, et al. Prevalence, severity and under-diagnosis of COPD in the primary care setting. Thorax 2008;63:402-07. http://dx.doi.org/10.1136/thx.2007.085456

155. Hardie JA, Buist AS, Vollmer WM, Ellingsen I, Bakke PS, Morkve O. Risk of over-diagnosis of COPD in asymptomatic elderly never smokers. Eur Respir 2002;20:1117-22. http://dx.doi.org/10.1183/09031936.02.00023202

156. Buffels J, Degryse J, Liistro G. Diagnostic certainly, co-morbidity and medication in a primary care population with presumed airway obstruction: the DIDASCO2 study. Prim Care Resp J 2009;18:34-40. http://dx.doi.org/10.3132/pcrj.2008.00047

157. Price $D$, Crockett $A$, Arne $M$, et al. Spirometry in primary care case-identification, diagnosis and management of COPD. Prim Care Resp J 2009;18:216-23. http://dx.doi.org/10.4104/pcrj.2009.00055

158. den Otter JJ, Knitel M, Akkermans RP, van Schayck CP, Folgering HT, van Weel C. Spirometry in general practice: the performance of practice assistants scored by lung function technicians. Br J Gen Pract 1997;47:41-2.

159. Price DB, Tinkelman DG, Halbert RJ, et al. Symptom-based questionnaire for identifying COPD in smokers. Respiration 2006;73:285-95. http://dx.doi.org/10.1159/000090142

160. Price DB, Tinkelman DG, Nordyke RJ, et al. COPD Questionnaire Study Group. Scoring system and clinical application of COPD diagnostic questionnaires. Chest 2006;129:1531-9. http://dx.doi.org/10.1378/chest.129.6.1531

161. Tinkelman DG, Price DB, Nordyke RJ, et al. Symptom-based questionnaire for differentiating COPD and asthma. Respiration 2006;73:296-305. http://dx.doi.org/10.1159/000090141

162. Soriano JB, Zielinski J, Price D. Screening for and early detection of chronic obstructive pulmonary disease. Lancet 2009;374:721-32. http://dx.doi.org/10.1016/ 6736(09)61290-3

163. Miller MR, Hankinson J, Brusasco V, et al. Standardisation of spirometry. Eur Respir J 2005;26:319-38. http://dx.doi.org/10.1183/09031936.05.00034805

164. Calverley P. Fulfilling the promise of primary care spirometry. Eur Respir J 2008;31:8-10 http://dx.doi.org/10.1183/09031936.00124507

165. Wilt TJ, Niewoehner D, Kim C, et al. Use of spirometry for case finding, diagnosis, and management of chronic obstructive pulmonary disease (COPD). Evid Rep Technol Assess 2005;121:1-7.

166. Jones P, Harding G, Wiklund I, Berry P, Leidy N. Improving the process and outcome of care in COPD: development of a standardised assessment tool. Prim Care Resp J 2009;18:208-15. http://dx.doi.org/10.4104/pcrj.2009.00053

167. Celli BR, Cote CG, Marin JM, et al. The Body-Mass Index, Airflow Obstruction, Dyspnea, and Exercise Capacity Index in Chronic Obstructive Pulmonary Disease. N Engl J Med 2004;350:1005-12. http://dx.doi.org/10.1056/NEJMoa021322

168. Puhan M, Garcia-Aymerich J, Frey M, et al. Expansion of the prognostic assessment of patients with chronic obstructive pulmonary disease: the updated BODE index and the ADO index. Lancet 2009;374:704-11. http://dx.doi.org/10.1016/S0140-6736(09) 61301-5

169. Jones RC, Donaldson GC, Chavannes NH, et al. Derivation and validation of a composite index of severity in chronic obstructive pulmonary disease- the DOSE index. Am J Respir. Crit Care Med 2009;180:1189-95. http://dx.doi.org/10.1164/rccm.200902-02710C

170. Fletcher CM, Elmes PC, Fairbairn AS, Wood CH. The Significance of Respiratory Symptoms and the Diagnosis of Chronic Bronchitis in a Working Population. BMJ 1959;2:257-66. http://dx.doi.org/10.1136/bmj.2.5147.257

171. Bestall JC, Paul EA, Garrod R, et al. Usefulness of the Medical Research Council (MRC) dyspnoea scale as a measure of disability in patients with chronic obstructive pulmonary disease. Thorax 1999;54:581-86. http://dx.doi.org/10.1136/thx.54.7.581

172. van der Molen T, Willemse BW, Schokker S, et al. Development, validity and responsiveness of the Clinical COPD Questionnaire. Health Qual Life Outcomes 2003; 1:13. http://dx.doi.org/10.1186/1477-7525-1-13

173. Jones P, Harding G, Berry P, Wiklund I, Chen W-H, Leidy N. Development and first validation of the COPD Assessment Test. Eur Respir J 2009;34:648-54. http://dx.doi.org/10.1183/09031936.00102509

174. Jones PW, Quirk FH, Baveystock CM. The St. George's Respiratory Questionnaire. Respir Med 1991;85(suppl B):25-31. http://dx.doi.org/10.1016/S0954-6111(06)80166-6

175. Mahler DA, Mackowiak Jl. Evaluation of the short-form 36-item questionnaire to measure health-related quality of life in patients with COPD. Chest 1995;107:1585-9. http://dx.doi.org/10.1378/chest.107.6.1585

176. Puhan MA, Guyatt GH, Goldstein R, et al. Relative responsiveness of the Chronic Respiratory Questionnaire, St Georges Respiratory Questionnaire and four other health-related quality of life instruments for patients with chronic lung disease. Respir Med 2007;101:308-16. http://dx.doi.org/10.1016/j.rmed.2006.04.023

177. van den Bemt $L$, Schermer T, Bor H, et al. The risk for depression comorbidity in patients with COPD. Chest 2009;135:108-14. http://dx.doi.org/10.1378/chest.08-0965

178. Barnes PJ, Celli BR. Systemic manifestations and comorbidities of COPD. Eur Respir 2009:33:1165-85. http://dx.doi.org/10.1183/09031936.00128008

179. Cleland J, Lee A, Hall S. Associations of depression and anxiety with gender, age, healthrelated quality of life and symptoms in primary care COPD patients. Fam Pract 2007;24:21723. http://dx.doi.org/10.1093/fampra/cmm009

180. Langhammer A, Forsmo S, Syversen U. Long-term therapy in COPD: any evidence of adverse effect on bone? Int J COPD 2009;4:365-80.

181. Janda S, Park K, Fitzgerald JM, et al. Statins in COPD: A Systematic Review. Chest 2009;136:734-43. http://dx.doi.org/10.1378/chest.09-0194

182. Barnes PJ. Future Treatments for Chronic Obstructive Pulmonary Disease and its Comorbidities. Proceedings Am Thoracic Soc 2008;5:857-64.

183. Carter R, Holiday DB, Nwasuruba C, Stocks J, Grothues C, Tiep B. 6-minute walk work for assessment of functional capacity in patients with COPD. Chest 2003;123:1408-15. http://dx.doi.org/10.1378/chest.123.5.1408

184. Schneider A, Dinant GJ, Maag I, et al. The added value of C-reactive protein to clinical signs and symptoms in patients with obstructive airway disease: results of a diagnostic study in primary care. BMC Fam Pract 2006;7:28. http://dx.doi.org/10.1186/1471-2296-7-28

185. Garrod R, Marshall J, Barley $E_{\text {, et }}$ al. The relationship between inflammatory markers and disability in chronic obstructive pulmonary disease (COPD). Prim Care Resp J 2007; 16:23640. http://dx.doi.org/10.3132/pcrj.2007.00047

186. Ram FSF, Wedzicha JA, Wright JJ, Greenstone M. Hospital at home for acute exacerbations of chronic obstructive pulmonary disease. Cochrane Database of Systematic Reviews 2003, Issue 4. Art. No: CD003573. http://dx.doi.org/10.1002/14651858.CD003573.

187. Ställberg B, Selroos O, Vogelmeier C, Andersson Eva, Ekström T, Larsson K Budesonide/formoterol as effective as prednisolone plus formoterol in acute exacerbations of COPD A double-blind, randomised, non-inferiority, parallel-group, multicentre study. Respir Res 2009;10:11. http://dx.doi.org/10.1186/1465-9921-10-11

188. Effing T, Monninkhof EEM, van der Valk PP, et al. Self-management education for patients with chronic obstructive pulmonary disease. Cochrane Database of Systematic Reviews 2007 Issue 4. Art. No.: CD002990. http://dx.doi.org/10.1002/14651858.CD002990.pub2.

189. Mc-Geoch GR, Willsman KJ, Dowson CA, et al. Self-management plans in the primary care of patients with chronic obstructive pulmonary disease. Respirology 2006;11:611-18. http://dx.doi.org/10.1111/.1440-1843.2006.00892.x

190. Kielmann T, Huby G, Powell A, et al. From support to boundary: a qualitative study of the border between self care and professional care. Pat Ed Counsel 2009, e-pub ahead of print. http://dx.doi.org/10.1016/j.pec.2009.07.015.

191. Kennedy A, Rogers A, Bower P. Support for self care for patients with chronic disease. $B M$ 2007;337:968-70. http://dx.doi.org/10.1136/bmj.39372.540903.94

192. Hernandez P, Balter M, Bourdeau J, Hodder R. Living with chronic obstructive pulmonary disease: A survey of patients knowledge and attitudes. Respir Med 2009;103:1004-12. http://dx.doi.org/10.1016/j.rmed.2009.01.018

193. Hansell AL, Walk JA, Soriano JB. What do chronic obstructive pulmonary disease patients die from? A multiple cause coding analysis. Eur Respir J 2003;22:809-14. http://dx.doi.org/10.1183/09031936.03.00031403

194. Habraken JM, Willems DL, de Kort SJ, Bindels PJE. Health care needs in end-stage COPD: A structured literature review. Pat Ed Counsel 2007:68:121-30. http://dx.doi.org/10.1016/j.pec.2007.05.011

195. Rocker GM, Sinuff T, Horton R, Hernandez P. Advanced chronic obstructive pulmonary disease: innovative approaches to palliation. I Palliat Med 2007;10:783-96. http://dx.doi.org/10.1089/jpm.2007.9951

196. Seamark DA, Seamark CJ, Halpin D. Palliative care in chronic obstructive pulmonary disease: a review for clinicians. JR SoC Med 2007;100:225-33. http://dx.doi.org/10.1258/jrsm.100.5.225

197. Lynn J. Ely EW. Zhong Z. McNiff KL. Dawson NV. Connors A. Desbiens NA. Claessens M. McCarthy EP. Living and dying with chronic obstructive pulmonary disease. J Am Geriatrics Soc 2000;48:S91-S100.

198. Goodridge D. People with chronic obstructive pulmonary disease at the end of life: a review of the literature. Int J Palliative Nursing 2006;12:390-6.

199. Gore JM, Brophy CJ, Greenstone MA. How well do we care for patients with end stage chronic obstructive pulmonary disease (COPD)? A comparison of palliative care and quality of life in COPD and lung cancer. Thorax 2000;55:1000-06 http://dx.doi.org/10.1136/thorax.55.12.1000

200. Coventry PA, Grande GE, Richards DA, Todd CJ. Prediction of appropriate timing of palliative care for older adults with non-malignant life-threatening disease: a systematic review. Age and Ageing 2005;34:218-227. http://dx.doi.org/10.1093/ageing/afi054

201. Christakis NA, Lamont EB. Extent and determinants of error in doctor's prognosis in terminally ill patients: prospective cohort study. BMJ 2000;320:469-72. 
http://dx.doi.org/10.1136/bmj.320.7233.469

202. Murray SA, Boyd K, Sheikh A. Palliative care in chronic illness. We need to move from prognostic paralysis to active total care. BMJ 2005;330:611-12. http://dx.doi.org/10.1136/bmj.330.7492.611

203. Murray S, Pinnock $H$, Sheikh A. Palliative care for people with COPD: we need to meet the challenge. Prim Care Resp J 2006;15:362-4. http://dx.doi.org/10.1016/ j.pcrj.2006.08.008

204. Pinnock H, Reid J. Palliative care for people with COPD. IPCRG Opinion 4: Aberdeen; IPCRG, 2008. available from http://www.theipcrg.org (accessed February 2010)

205. Chavannes NH, Grijsen M, Akker M et al. Integrated disease management improves one-year quality of life in primary care COPD patients. Prim Care Resp J 2009;18:171-6.

206. Taylor SJC, Candy B, Bryar RM, et al. Effectiveness of innovations in nurse led chronic disease management for patients with chronic obstructive pulmonary disease: systematic review of evidence. BMJ 2005;331:485-8. http://dx.doi.org/10.1136/ bmj.38512.664167.8F

207. Casas A, Troosters T, Garcia-Aymerich J, et al. Integrated care prevents hospitalisations for exacerbations in COPD patients. Eur Respir J 2006;28:1-8. http://dx.doi.org/ 10.1183/09031936.06.00063205

208. Lacasse Y, Goldstein R, Lasserson TJ, Martin S. Pulmonary rehabilitation for chronic obstructive pulmonary disease. Cochrane Database of Systematic Reviews 2006, Issue 4. Art. No.: CD003793. http://dx.doi.org/10.1002/14651858.CD003793.pub2.

209. World Health Organization. World health statistics 2006. Geneva: WHO press, 2006 Available from http://www.who.int/whosis/whostat2006/en/index.htm (accessed February 2010)

210. World Health Organization. Prevention and control of noncommunicable diseases: implementation of the global strategy. Geneva; WHO, 2008. Available from http://www.who.int/nmh/NCD\%20Action\%20Plan\%20Resolution.pdf Accesssed February 2101)

211. Peto R, Lopez AD, Boreham J, et al. Mortality from smoking worldwide. Br Med Bull 1996:52:12-21.

212. Pinnock H (editor), van Schayck O (Chairman) for the IPCRG Smoking Cessation Guidance group). Tackling the Smoking Epidemic. Aberdeen; IPCRG, 2007. Available from http://www.theipcrg.org/smoking/index.php (accessed February 2010).

213. World Bank. Curbing the epidemic: governments and the economics of tobacco control. Washington, DC: World Bank, 1999. Available from www1.worldbank.org/tobacco/reports.asp (accessed February 2010).

214. Warner KE, Mackay JL. Smoking cessation treatment in a public-health context. Lancet 2008;371:1976-8. http://dx.doi.org/10.1016/50140-6736(08)60846-6

215. U.S. Department of Health and Human Services. Preventing Tobacco Use Among Young People: A Report of the Surge\& General. Atlanta, Georgia: HSS, 1994.

216. Lumley J, Chamberlain C, Dowswell T, Oliver S, Oakley L, Watson L. Interventions for promoting smoking cessation during pregnancy. Cochrane Database of Systematic Reviews 2009, Issue 3. Art. No.: CD001055. http://dx.doi.org/0.1002/ 14651858.CD001055.pub3.

217. Al-Shawwa B, Al-Huniti N, Weinberger M, Abu-Hasan M. Clinical and therapeutic variables influencing hospitalisation for bronchiolitis in a community-based paediatric group practice. Prim Care Resp J 2007;16:93-7. http://dx.doi.org/10.3132/ pcri.2007.00018

218. Kum-Nji P, Meloy L, Herrod HG. Environmental tobacco smoke exposure: prevalence and mechanisms of causation of infections in children. Pediatrics 2006;117:1745-54. http://dx.doi.org/10.1542/peds.2005-1886

219. Nilsson P, Köhler M, Ostergren PO, Khan FA. Children exposed to environmental smoking have a higher antibiotic consumption. Vaccine 2007:25:2533-5. http://dx.doi.org/10.1016/j.vaccine.2006.09.031

220. MacKay J, Eriksen M. The Tobacco Atlas 3rd ed. World Health Organization. Geneva: WHO, 2002 http://www.who.int/tobacco/statistics/tobacco_atlas/en

221. Hurley SF, Matthews JP. Cost-effectiveness of the Australian National Tobacco Campaign Tobacco Control 2008;17:379-84. http://dx.doi.org/10.1136/tc.2008.025213

222. Wakefield MA, Durkin S, Spittal MJ, et al. Impact of tobacco control policies and mass media campaigns on monthly adult smoking prevalence. Am J Public Health 2008;98: 1443-50. http://dx.doi.org/10.2105/AJPH.2007.128991

223. Lemmens V, Oenema A, Knut IK, Brug J. Effectiveness of smoking cessation interventions among adults: a systematic review of reviews. Eur J Cancer Prev 2008;17: 535-44. http://dx.doi.org/10.1097/CEJ.0b013e3282f75e48

224. Rice VH, Stead LF. Nursing interventions for smoking cessation. Cochrane Database of Systematic Reviews 2008, Issue 1. Art. No.: CD001188. http://dx.doi.org/10.1002/14651858.CD001188.pub.

225. Stead LF, Bergson G, Lancaster T. Physician advice for smoking cessation. Cochrane Database of Systematic Reviews 2008, Issue 2. Art. No.: CD000165. http://dx.doi.org/10.1002/14651858.CD000165.pub3

226. World Health Organization. WHO Framework Convention on Tobacco Control. Geneva: WHO, 2003 Available from http://www.who.int/fctc/en/ (accessed February 2010).

227. Gilbert AR, Pinget $C$, Bovet $P$, Cornuz J, Shamlaye C, Paccaud F. The cost effectiveness of pharmacological smoking cessation therapies in developing countries: a case study in the Seychelles. Tobacco Contro/ 2004;13:190-5. http://dx.doi.org/10.1136/ tc.2003.004630

228. Richmond R, Kehoe L, Webster I, Wodak A, Heather N. General practitioners' promotion of healthy lifestyles: what patients think. Aust NZ J Public Health 1996; 20:195-200. http://dx.doi.org/10.1111/j.1753-6405.1996.tb01818.x
229. Ferguson SG, Shiffman S, Gitchell JG, Sembower MA West R. Unplanned quit attempts-results from a U.S. sample of smokers and ex-smokers. Nicotine Tobacco Res 2009;11: 82732. http://dx.doi.org/10.1093/ntr/ntp072

230. Murray RL, Lewis SA, Coleman T, Britton J, McNeill A. Unplanned attempts to quit smoking: missed opportunities for health promotion? Addiction 2009;104:1901-09. http://dx.doi.org/10.1111/j.1360-0443.2009.02647.x

231. Gage JD, Everett KD, Bullock $L$. A review of research literature addressing male partners and smoking during pregnancy. J Obstet Gynecol Neonatal Nursing 2007;36:574-80.

232. Naughton FA, Prevost T, Sutton S. Self-help smoking cessation interventions in pregnancy: a systematic review and meta-analysis. Addiction 2008;103:566-79. http://dx.doi.org/10.1111//.1360-0443.2008.02140.x

233. Grimshaw G, Stanton A. Tobacco cessation interventions for young people. Cochrane Database of Systematic Reviews 2006, Issue 4. Art. No.: CD003289. http://dx.doi.org/10.1002/14651858.CD003289.pub4.

234. Gelenberg AJ, de Leon J, Evins AE, Parks JJ, Rigotti NA. Smoking cessation in patients with psychiatric disorders. J Clin Psychiatry 2007;68:1404-10. http://dx.doi.org/ 10.4088/JCP.v68n0912

235. Hitsman B, Moss TG, Montoya ID, George TP. Treatment of tobacco dependence in menta health and addictive disorders. Can J Psychiatry 2009;54:368-78.

236. Siru R, Hulse GK, Tait RJ. Assessing motivation to quit smoking in people with mental illness: a review. Addiction 2009;104:719-33. http://dx.doi.org/10.1111/j.13600443.2009.02545.x

237. Fiore MC, Jaén CR, Baker TB. Treating Tobacco Use and Dependence: 2008 Update. Rockville, MD; U.S. Department of Health and Human Services. Public Health Service. 2008.

238. Feenstra TL, Hamberg van Reenen HH, Hoogenveen RT, Rutten-van Mölken MP. Costeffectiveness of face-to-face smoking cessation interventions: a dynamic modeling study. Value Health 2005;8:178-90. http://dx.doi.org/10.1111/.1524-4733.2005.04008.x

239. Litt J. How to provide effective smoking cessation advice in less than a minute without offending the patient. Aust Fam Physician 2002;31:1087-94.

240. Stange KC, Woolf SH, Gjeltema K. One minute for prevention. The power of leveraging to fulfil promise of health behaviour counseling. Am J Prev Med 2002;22:320-3. http://dx.doi.org/10.1016/S0749-3797(02)00413-0

241 Cahill $K$, Stead LF, Lancaster T. Nicotine receptor partial agonists for smoking cessation. Cochrane Database of Systematic Reviews 2008, Issue 3. Art. No.: CD006103. http://dx.doi.org/10.1002/14651858.CD006103.pub3.

242. Cerny E H, Cerny T. Anti-nicotine abuse vaccines in the pipeline: an update. Expert Opin Investig Drugs 2008;17:691-6. http://dx.doi.org/10.1517/13543784.17.5.691

243. Cornuz J, Zwahlen S, Jungi WF, et al. A vaccine against nicotine for smoking cessation: a randomized controlled trial. PLOS ONE 2008;3:e2547. http://dx.doi.org/ 10.1371/journal.pone.0002547

244. Wagena EJ, de Vos A, Horwith G, van Schayck CP, et al. The immunogenicity and safety of a nicotine vaccine in smokers and nonsmokers: results of a randomized, placebo-controlled phase 1/2 trial. Nicotine Tobacco Res 2008;10:213-18. http://dx.doi.org/10.1080/14622200701704921

245. Hajek P, Stead LF, West R, Jarvis M, Lancaster T. Relapse prevention interventions for smoking cessation. Cochrane Database of Systematic Reviews 2009, Issue 1. Art. No.: CD003999. http://dx.doi.org/10.1002/14651858.CD003999.pub3.

246. Jacot Sadowski I, Ruffieux C, Cornuz J. Self-reported smoking cessation activities among Swiss primary care physicians. BMC Fam Pract 2009;10:22. http://dx.doi.org/10.1186/14712296-10-22

247. Stead LF, Perera $R$, Lancaster $T$, et al. A systematic review of interventions for smokers who contact quitlines. Tobacco Control 2007; 16(Suppl 1):i3-8. http://dx.doi.org/10.1136/tc.2006.019737

248. Holtrop J, Malouin R, Weismantel D, Wadland W. Clinician perceptions of factors influencing referrals to a smoking cessation program. BMC Fam Pract 2008;9:18 http://dx.doi.org/10.1186/1471-2296-9-18

249. McRobbie $H$, Hajek P, Feder G, Eldridge S. A cluster-randomised controlled trial of a brief training session to facilitate general practitioner referral to smoking cessation treatment. Tobacco Control 2008;17:173-6. http://dx.doi.org/10.1136/tc.2008.024802

250. Zbikowski SM, Hapgood J, Smucker Barnwell S, McAfee T. Phone and web-based tobacco cessation treatment: real-world utilization patterns and outcomes for 11,000 tobacco users. J Med Internet Res 2008;10: e41. http://dx.doi.org/10.2196//mir.999

251. Hughes J, Marcy T, Naud S. Interest in treatments to stop smoking. J Subst Abuse Treat 2009:36:18-24. http://dx.doi.org/10.1016/.jsat.2008.04.002

252. Balmford J, Borland R, Li L, Ferretter I. Usage of an Internet smoking cessation resource: the Australian QuitCoach. Drug Alcohol Rev 2009;28: 66-72.

253. World Health Organization. Factsheet 310: Top ten causes of death. Geneva: WHO, 2008 Available from http://www.who.int/mediacentre/factsheets/fs310/en/index.html (Accessed February 2010)

254. Holmes WF, Macfarlane J. Issues at the interface between primary and secondary care in the management of common respiratory disease. Introduction. Thorax 1999;54:538-9.

255. Goossens H, Ferech M, Vander Stichele R, Elseviers M. Outpatient antibiotic use in Europe and association with resistance: a cross-national database study. Lancet 2005:365:579-87.

256. Arroll B, Kenealy T. Antibiotics for the common cold and acute purulent rhinitis. Cochrane 
Database of Systematic Reviews 2005, Issue 3. Art. No.: CD000247. http://dx.doi.org/ 10.1002/14651858.CD000247.pub2.

257. Spinks A, Glasziou PP, Del Mar C. Antibiotics for sore throat. Cochrane Database of Systematic Reviews 2006, Issue 4. Art. No.: CD000023. http://dx.doi.org/ 10.1002/14651858.CD000023.pub3.

258. Sanders S, Glasziou PP, Del Mar C, Rovers MM. Antibiotics for acute otitis media in children. Cochrane Database of Systematic Reviews 2004, Issue 1. Art. No.: CD000219. http://dx.doi.org/10.1002/14651858.CD000219.pub2.

259. Smith SM, Fahey T, Smucny J, Becker LA. Antibiotics for acute bronchitis. Cochrane Database of Systematic Reviews 2004, Issue 4. Art. No.: CD000245. http://dx.doi.org/10.1002/14651858.CD000245.pub2.

260. Levy SB. Factors impacting on the problem of antibiotic resistance. J Antimicrob Chemother 2002;49:25-30. http://dx.doi.org/10.1093/jac/49.1.25

261. Metlay JP, Powers JH, Dudley MN, Christiansen K, Finch RG. Antimicrobial drug resistance, regulation, and research. Emerg Infect Dis 2006;12:183-90.

262. Butler CC, Dunstan F, Heginbothom M, et al. Containing antibiotic resistance: decreased antibiotic-resistant coliform urinary tract infections with reduction in antibiotic prescribing by general practices. Br J Gen Pract 2007; 57:785-92.

263. Goossens H, Ferech M, Coenen S, Stephens P. Comparison of outpatient systemic antibacterial use in 2004 in the United States and 27 European countries. Clin Infect Dis 2007:44:1091-5. http://dx.doi.org/10.1086/512810

264. Winchester CC, Macfarlane TV, Thomas M, Price D. Antibiotic prescribing and outcomes of lower respiratory tract infection in UK primary care. Chest 2009;135:1163-72. http://dx.doi.org/10.1378/chest.07-2940

265. Macfarlane J, Holmes WF, Macfarlane R. Do hospital physicians have a role in reducing antibiotic prescribing in the community? Thorax 2000;55:153-8. http://dx.doi.org/10.1136/thorax.55.2.153

266. The stop TB partnership. The Global Plan to stop TB. Available from http://www.stoptb.org/globalplan (accessed February 2010)

267. Creer DD, Dilworth JP, Gillespie SH, et al. Aetiological role of viral and bacterial infections in acute adult lower respiratory tract infection (LRTI) in primary care. Thorax 2006;61:75-9. http://dx.doi.org/10.1136/thx.2004.027441

268. Hopstaken RM, Stobberingh EE, Knottnerus JA, et al. Clinical items not helpful in differentiating viral from bacterial lower respiratory tract infections in general practice. J Clin Epidemio/ 2005;58:175-83. http://dx.doi.org/10.1016/.jclinepi.2004.08.004

269. Holm A, Nexoe J, Bistrup LA, et al. Aetiology and prediction of pneumonia in lower respiratory tract infection in primary care. Br J Gen Pract 2007; 57:547-54.

270. Fiebach N, Beckett W. Prevention of Respiratory Infections in Adults: Influenza and Pneumococcal vaccines. Arch Intern Med 1994;154:2545-57. http://dx.doi.org/ 10.1001/archinte.154.22.2545

271. Williams JM. 2009 update in prevention, evaluation, and outpatient treatment of influenza. Curr Med Res Opin 2009;25:817-28. http://dx.doi.org/ 10.1185/03007990802708244

272. Hopstaken RM, Cals JW, Dinant GJ. Accuracy of lipopolysaccharide-binding protein (LBP) and fibrinogen compared to C-reactive protein (CRP) in differentiating pneumonia from acute bronchitis in primary care. Prim Care Resp J 2009;18:227-30. http://dx.doi.org/10.4104/pcrj.2009.00011

273. Hopstaken RM, Muris JWM, Knottnerus JA, Kester ADM, Rinkens PELM, Dinant GJ. Contributions of symptoms, signs, erythrocyte sedimentation rate and C-reactive protein to a diagnosis of pneumonia in acute lower respiratory tract infection. $\mathrm{Br} / \mathrm{Gen}$ Pract 2003;53:358-64.

274. Melbye $H$, Straume B, Aasebo U, Brox J. The diagnosis of adult pneumonia in general practice. The diagnostic value of history, physical examination and some blood tests. Scand J Prim Health Care 1988:6:111-17. http://dx.doi.org/10.3109/02813438809009300

275. Cals JW, Butler CC, Hopstaken RM, Hood K, Dinant GJ. Effect of point of care testing for C reactive protein and training in communication skills on antibiotic use in lower respiratory tract infections: cluster randomised trial. BMJ 2009;338:b1374. http://dx.doi.org/1 0.1136/bmj.b1374

276. Briel M, Young J, Tschudi $P$, et al. Prevalence and influence of diagnostic tests for acute respiratory tract infections in primary care. Swiss Med Wkly 2006;136:248-53.

277. Engström S, Mölstad S, Lindström K, et al. Excessive use of rapid tests in respiratory tract infections in Swedish primary health care. Scand J Infect Dis 2004;36:213-18. http://dx.doi.org/10.1080/00365540310018842

278. Katz MA, Lamias MJ, Shay DK, Uyeki TM. Use of rapid tests and antiviral medications for influenza among primary care providers in the United States. Influenza Other Respir Viruses 2009;3:29-35. http://dx.doi.org/10.1111//.1750-2659.2009.00070.x

279. Hak E, Rovers MM, Kuyvenhoven MM, Schellevis FG, Verheij TJ. Incidence of GP-diagnosed respiratory tract infections according to age, gender and high-risk co-morbidity: the Second Dutch National Survey of General Practice. Fam Pract 2006;23:291-4. http://dx.doi.org/10.1093/fampra/cmi121

280. Hak E, Bont J, Hoes AW, Verheij TJ. Prognostic factors for serious morbidity and mortality from community-acquired lower respiratory tract infections among the elderly in primary care. Fam Pract 2005:22:375-80. http://dx.doi.org/10.1093/fampra/cmi020

281. File TM. The epidemiology of respiratory tract infections. Semin Respir Infect 2000;15:18494. http://dx.doi.org/10.1053/srin.2000.18059

282. Venmans LM, Bont J, Gorter KJ, Verheij TJ, Rutten GE, Hak E. Prediction of complicated lower respiratory tract infections in older patients with diabetes. Br J Gen Pract 2008;58:564-8.

283. van de Nadort C, Smeets HM, Bont J, Zuithoff NP, Hak E, Verheij TJ. Prognosis of primary care patients aged 80 years and older with lower respiratory tract infection. $\mathrm{Br} J$ Gen Pract 2009;59:110-15. http://dx. doi.org/10.3399/bjgp09X420239

284. Bont J, Hak E, Birkhoff CE, Hoes AW, Verheij TJ. Is co-morbidity taken into account in the antibiotic management of elderly patients with acute bronchitis and COPD exacerbations? Fam Pract 2007;24:317-22. http://dx.doi.org/10.1093/fampra/cmm023

285. Woodhead M, Blasi F, Ewig S, et al. Guidelines for the management of adult lower respiratory tract infections. Eur Respir J 2005;26:1138-80. http://dx.doi.org/ 10.1183/09031936.05.00055705

286. Bont J, Hak E, Hoes AW, Macfarlane JT, Verheij TJ. Predicting death in elderly patients with community-acquired pneumonia: a prospective validation study reevaluating the CRB-65 severity assessment tool. Arch Intern Med 2008;168:1465-8. http://dx.doi.org/10.1001/archinte.168.13.1465

287. Bont J, Hak E, Hoes AW, Schipper M, Schellevis FG, Verheij TJ. A prediction rule for elderly primary-care patients with lower respiratory tract infections. Eur Respir J 2007;29:969-75. http://dx.doi.org/10.1183/09031936.00129706

288. Lim WS, Baudouin SV, George RC, et al. for the Pneumonia Guidelines Committee of the BTS Standards of Care Committee. BTS guidelines for the management of community acquired pneumonia in adults: update 2009. Thorax 2009;64(Suppl 3):iii1-55 http://dx.doi.org/10.1136/thx.2009.121434

289. Vinogradova Y, Hippisley-Cox J, Coupland C. Identification of new risk factors for pneumonia: population-based case-control study. Br J Gen Pract 2009;59:e329-38. http://dx.doi.org/10.3399/bjgp09X472629

290. Stanton N, Hood K, Kelly MJ, et al. Are smokers with acute cough in primary care prescribed antibiotics more often, and to what benefit? - An observational study in 13 European countries. Eur Respir J 2009, http://dx.doi.org/10.1183/09031936.00168409

291. Winchester CC, Macfarlane T, Thomas M, Price DB. Antibiotic prescribing and outcomes of lower respiratory tract infection in UK primary care. Chest 2009:135:1163-72. http://dx.doi.org/10.1378/chest.07-2940

292. Wise R, Hart T, Cars O, et al. Antimicrobial resistance: is a major threat to public health. $B M J$ 1998:317:609-10.

293. Macfarlane J, Holmes W, Gard P, Thornhill D, Macfarlane R, Hubbard R. Reducing antibiotic use for acute bronchitis in primary care: blinded, randomised controlled trial of patient information leaflet. BMJ 2002;324:91-4. http://dx.doi.org/10.1136/ bmj.324.7329.91

294. Holmes WF, Macfarlane JT, Macfarlane RM, Lewis S. The influence of antibiotics and other factors on reconsultation for acute lower respiratory tract illness in primary care. Br J Gen Pract 1997:47:815-18.

295. Cals JW, Hood K, Aaftink N, et al. Predictors of patient-initiated reconsultation for lower respiratory tract infections in general practice. $\mathrm{Br} J$ Gen Pract 2009;59:761-4. http://dx.doi.org/10.3399/bjgp09X472656

296. Cals JW, Hopstaken RM, Le Doux PH, Driessen GA, Nelemans PJ, Dinant GJ. Dose timing and patient compliance with two antibiotic treatment regimens for lower respiratory tract infections in primary care. Int J Antimicrob Agents 2008;31:531-6. http://dx.doi.org/10.1016/j.jiantimicag.2008.01.029

297. Coenen S, Goossens H. Antibiotics for respiratory tract infections in primary care. BMJ 2007;335:946-7. http://dx.doi.org/10.1136/bmj.39357.571343.80

298. Butler CC, Hood K, Verheij T, et al. Variation in antibiotic prescribing and its impact on recovery in patients with acute cough in primary care: prospective study in 13 countries. $B M J$ 2009;338:b2242. http://dx.doi.org/10.1136/bmj.b2242

299. Feldman C. Appropriate management of lower respiratory tract infections in primary care. Prim Care Resp J 2004;13:159-66. http://dx.doi.org/10.1016/j.pcrj.2004.02.006

300. Little P, Rumsby K, Kelly J, et al. Information Leaflet and Antibiotic Prescribing Strategies for Acute Lower Respiratory Tract Infection: A Randomized Controlled Trial. JAMA 2005;293:3029-35. http://dx.doi.org/10.1001/jama.293.24.3029

301. Smith SM, Schroeder K, Fahey T. Over-the-counter medications for acute cough in children and adults in ambulatory settings. Cochrane Database of Systematic Reviews 2008, Issue 1 Art. No.: CD001831. http://dx.doi.org/10.1002/14651858. CD001831.pub3

302. Scottish Intercollegiate Guideline Network. Guideline 59: Community Management of Lower Respiratory Tract Infection in Adults. Edinburgh: SIGN 2002.

303. Levy ML, Le Jeune I, Woodhead MA, Macfarlane JT, Lim WS. Primary care summary of the British Thoracic Society Guidelines for the management of community acquired pneumonia in adults: 2009 update. Prim Care Resp J 2010;19(1):21-7. http://dx.doi.org/10.4104/pcrj.2010.00014

\section{Available online at http://www.thepcrj.org}

